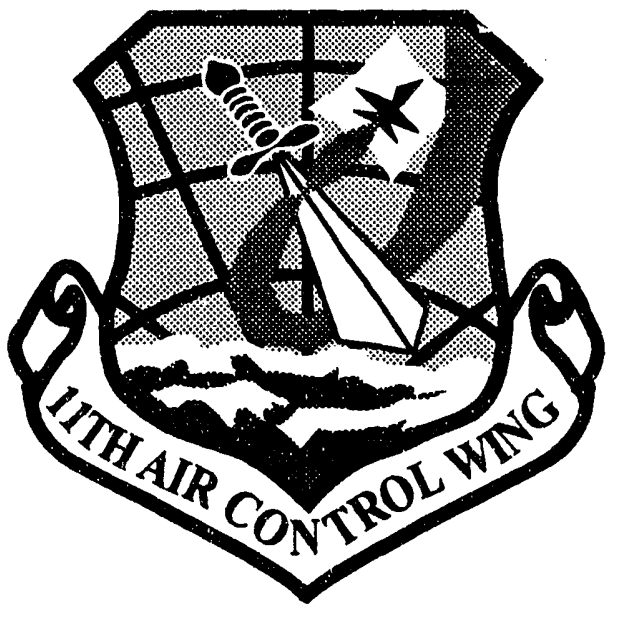

\title{
Shemya Air Force Base, Alaska No Further Action Decision Document for $\mathrm{Hg}-1$
}

EMO-- 1101

FINAL

DE93 012833

5 March 1993

Prepared for

U.S. Air Force

Elmendorf AFB, Alaska

11th Air Control Wing

11th Civil Engineering Operations Squadron Under Contract DEU-91-06

Prepared by

CH2M HILL

P.O. Box 8748

Boise, Idaho 83707

For

Environmentai Management Operations

Under a Related Services Agreement

with the U.S. Department of Energy

Environmental Management Operations

Richland, Washington 99352 
1.0 Introduction/Summary $\ldots \ldots \ldots \ldots \ldots \ldots \ldots \ldots \ldots \ldots \ldots \ldots \ldots$

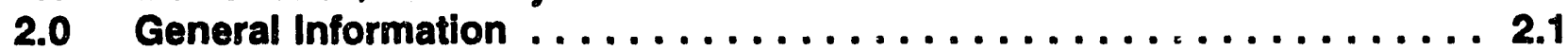

2.1 Description of Shemya AFB $\ldots \ldots \ldots \ldots \ldots \ldots \ldots \ldots \ldots 2.1$

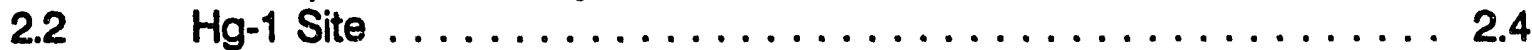

$2.3 \quad$ Adjacent Sites $\ldots \ldots \ldots \ldots \ldots \ldots \ldots \ldots \ldots \ldots \ldots \ldots .4 . \ldots \ldots \ldots$

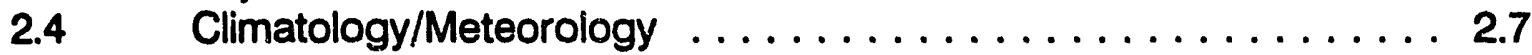

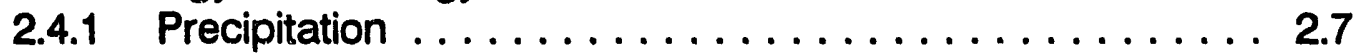

2.4 .2 Temperature . . . . . . . . . . . . . . . 2.7

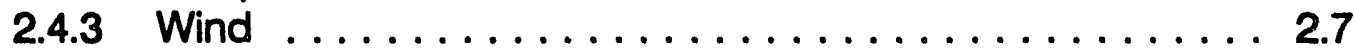

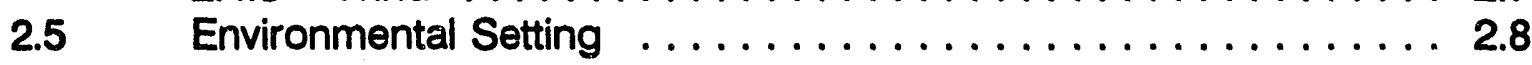

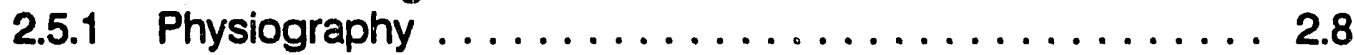

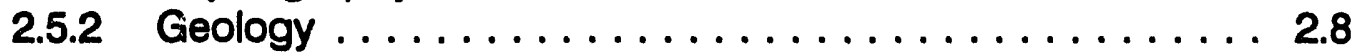

3.0 Data Collection/Data Evaluation $\ldots \ldots \ldots \ldots \ldots \ldots \ldots \ldots \ldots \ldots \ldots .1$

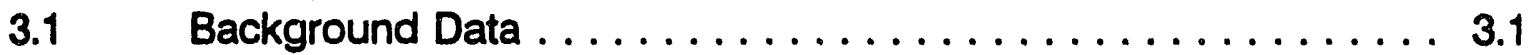

3.2 Sample Collection $\ldots \ldots \ldots \ldots \ldots \ldots \ldots \ldots \ldots \ldots \ldots \ldots \ldots \ldots$

3.3 Data Evaluation ........................ 3.4

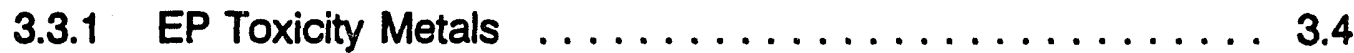

3.3.2 Mercury $\ldots \ldots \ldots \ldots \ldots \ldots \ldots \ldots \ldots \ldots \ldots . .4 .4$

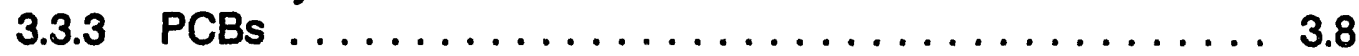

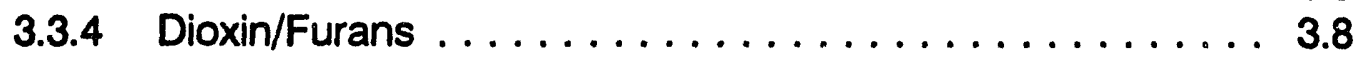

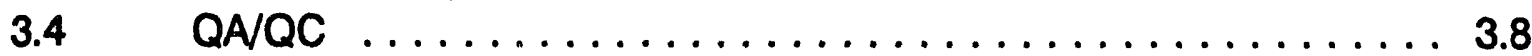

4.0 Exposure Routes $\ldots \ldots \ldots \ldots \ldots \ldots \ldots \ldots \ldots \ldots \ldots \ldots \ldots \ldots \ldots . \ldots \ldots$

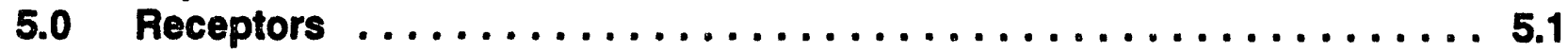

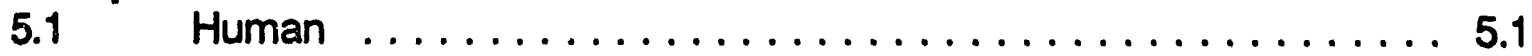

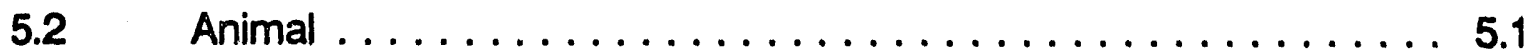

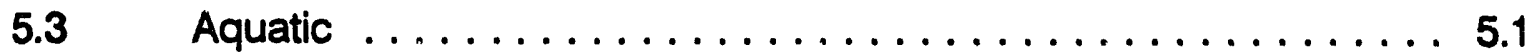

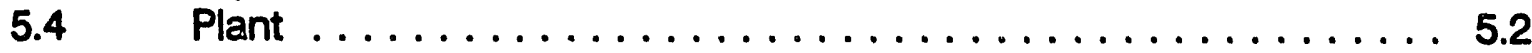

6.0 Risk Assessment $\ldots \ldots \ldots \ldots \ldots \ldots \ldots \ldots \ldots \ldots \ldots \ldots \ldots \ldots .1$

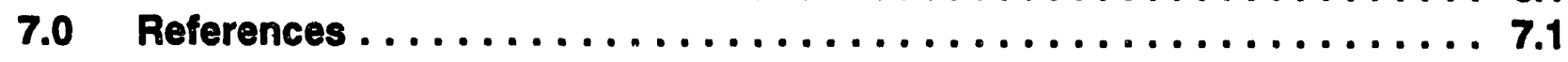


Appendix A. Laboratory Results for Sample Area $\mathrm{Hg}-1 \ldots \ldots \ldots \ldots \ldots \ldots$. . . . . . Appendix B. Laboratory Results for Background

\section{FIGURES}

$2.1 \quad$ Location Map $\ldots \ldots \ldots \ldots \ldots \ldots \ldots \ldots \ldots \ldots \ldots \ldots \ldots \ldots \ldots \ldots \ldots \ldots \ldots \ldots .2$

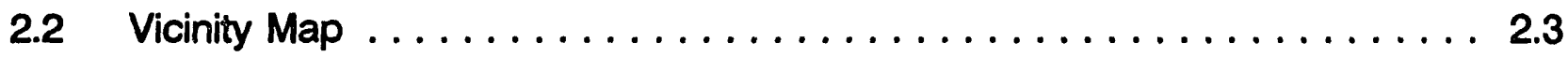

2.322 Sites Included in IRP Plan Scope of Work . . . . . . . . . . . . 2.5

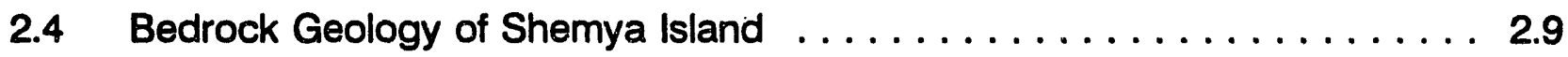

2.5 Surficial Deposits of Shemya Island . . . . . . . . . . . . . . 2.11

3.1 Sample Area Hg-1 Mercury and PCB Sampling Points . . . . . . . . . . . 3.7

\section{TABLES}

3.1 Analytical Results for Soil Samples--Background Metals . . . . . . . . . 3.2

3.2 Laboratory Test Results for Soil Samples Area $\mathrm{Hg}-1 \ldots \ldots . \ldots . . . \ldots 3$ 


\subsection{INTRODUCTION/SUMMARY}

This document is being prepared to document that a No Further Action Decision (NFAD) document is appropriate for the $\mathrm{Hg}-1$ site at Shemya Air Force Base (AFB), Alaska, under the Air Force Installation Restoration Program (IRP). The IRP is a Department of Defense (DOD) program established to identify and remediate hazardous waste problems on DOD property that result from past practices. The Alaska Department of Environmental Conservation (ADEC) draft document "No Further Action Criteria for DOD Military/FUD Sites" has been used as a guide in preparing this document.

Air Force personnel have stated that the $\mathrm{Hg}-1$ site may have been used to store mercury and PCB-contaminated material. The site was added to the IRP in 1987, and later that year a field investigation was conducted at the site. Soil samples were collected and analyzed for mercury, EP toxicity, polychlorinated biphenyls (PCBs), and dioxin. All concentrations of contaminants found in Area $\mathrm{Hg}-1$ are below regulatory action levels for PCBs (40 CFR 761) and mercury (55 FR 30798) or below detection levels for dioxin/furans. Therefore, leaving these soils in place is acceptable. 


\subsection{GENERAL INFORMATION}

\subsection{DESCRIPTION OF SHEMYA AFB}

Shemya Air Force Base (AFB) occupies the 3.5-mile-long by 1.5-mile-wide Shemya Island. The island is located at the viestern tip of the Aleutian Archipelago, 1,500 miles southwest of Anchorage. Figures 2.1 and 2.2 are the Location Map and Vicinity Map, respectively, for Shemya AFB.

The Air Force installation occupies the entire Shemya Island, which is accessible only by air or water. Major land use within the installation boundaries is that of support facilities, including buildings; roads; a runway; petroleum, oil and lubricants (POL) tank farms; training areas; and waste disposal areas.

One of the few low-lying platforms in the windswept western islands, it was first developed in May 1943 by the U.S. Army's 4th Infantry Regiment and the 18th Engineering Regiment, which constructed an airfield for use in the war campaign against the Japanese occupational forces then on Attu, Agattu, and Kiska Islands (Ross 1969). Shemya Air Force Station activities were. reduced following World War $I$, but the island again served as a refueling and staging point on the Great Circle Route for air support and supplies duing the Korean conflict. When the Korean conflict terminated, activities on Shemya once again were reduced and on July 1,1954 , the base was declared surplus and inactivated. Facilities were transferred to the Civil Aeronautics Authority (CAA) in 1955 and subsequently leased to a commercial carrier (Northwest Airlines) for support and communication purposes.

The Air Force returned to Shemya in 1958 in support of various Air Force and Army strategic intelligence collection activities. Shemya was redesignated from an Air Force Station to an Air Force Base on June 21, 1968. The base mission has been and remains an early warning radar installation whose principal purpose involves monitoring space and missile activities.

Approximately 700 military and civil service personnel are stationed at Shemya AFB. The population of the island can increase to approximately 1,000 during the summer construction season. 


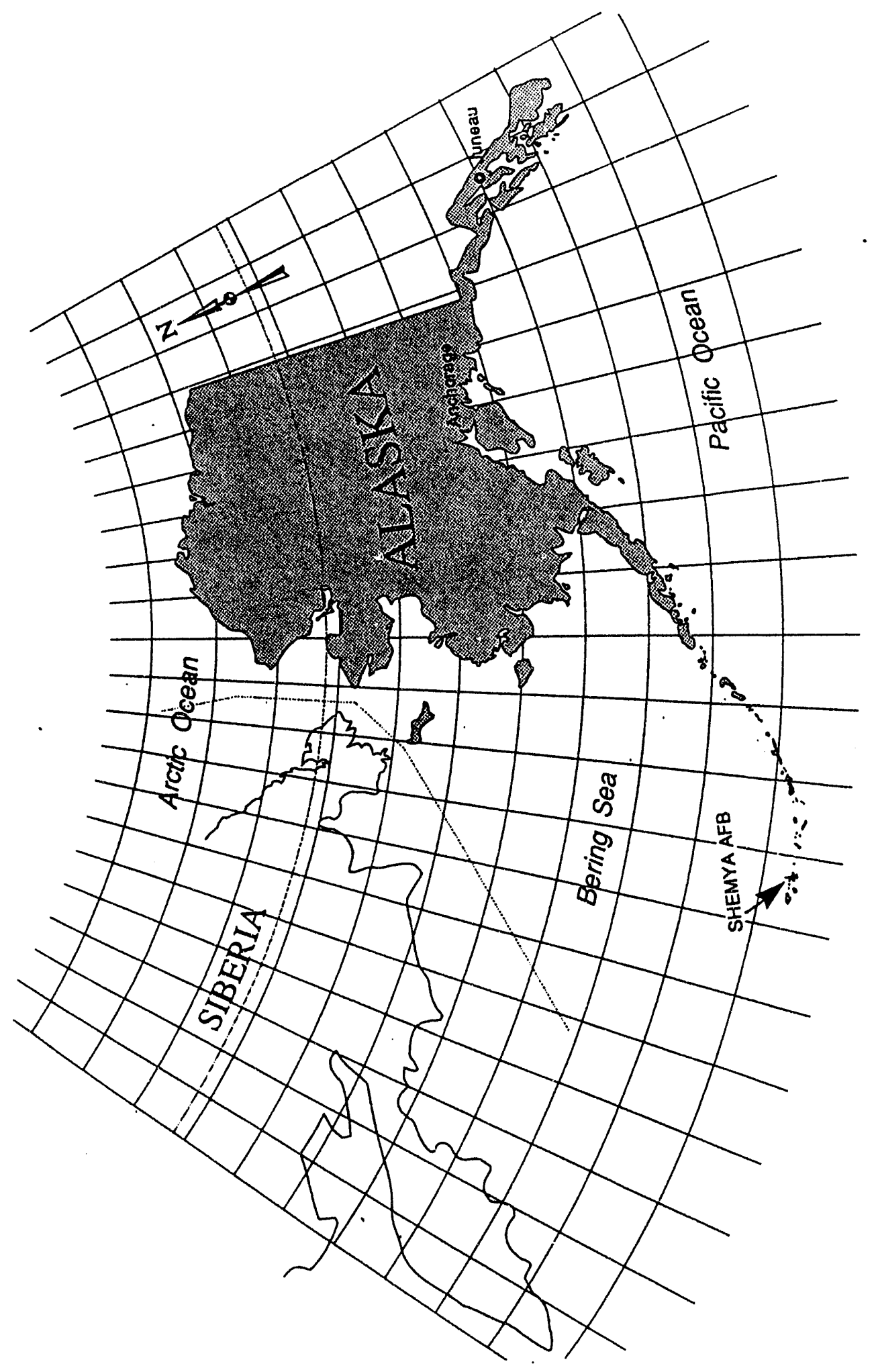

$m$
0
0
$\frac{1}{0}$
$\frac{1}{0}$
$\sum$
$n$

0
0
$ㄷ$
$\frac{0}{0}$
0
0
0

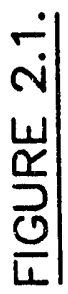




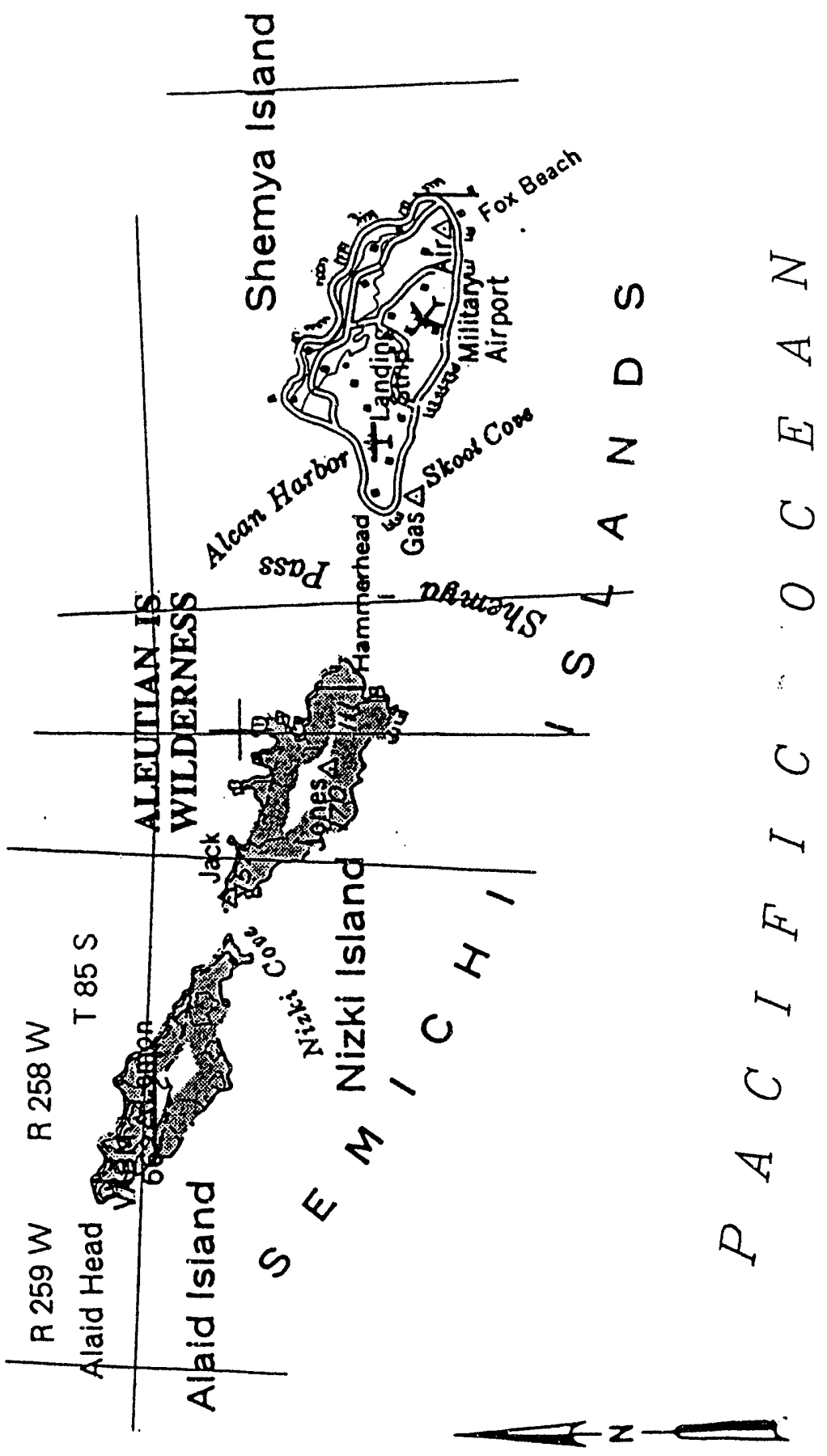


The island lies within the Aleutian Wildlife Refuge under the supervision of the U.S. Fish and Wildlife Service. The current agreement between the U.S. Fish and Wildlife Service and the USAF allows the Air Force to use the island as long as necessary. Once the Air Force no longer needs the island, the island may be returned to use as a wildlife refuge or be used as a commercial refueling station.

The IRP is a DOD program established to identify and remediate hazardous waste problems on DOD property that result from past practices. The intent of the IRP is to:

- Identify and evaluate past hazardous material disposal sites on DOD property.

- Control the mitigation of hazardous contaminants.

- Control hazards to health and welfare or the environment that may res'lt from those past disposal practices.

\section{$2.2 \mathrm{Hg}-1$ SITE}

The Hg-1 site is located east of the current DOD Anders Building, near the antenna field. This is the site of several building foundations and some building rubble. Air Force personnel have stated that the buildings that were once there may have been used to store mercury and PCB-contaminated waste material. However, no confirmation data can be obtained from Air Force personnel or files to support this statement. Since site contamination was suspected, the Air Force added this site to the IRP in 1987.

The 1988 field investigation team was unable to find any visible signs of mercury contamination at the site.

\subsection{ADJACENT SITES}

Figure 2.3 presents the other IRP sites located on Shemya Island. Four of these sites, SW-5, PS-8, PS-9, and PS-83, are located within 1 mile of the $\mathrm{Hg}-1$ site. 


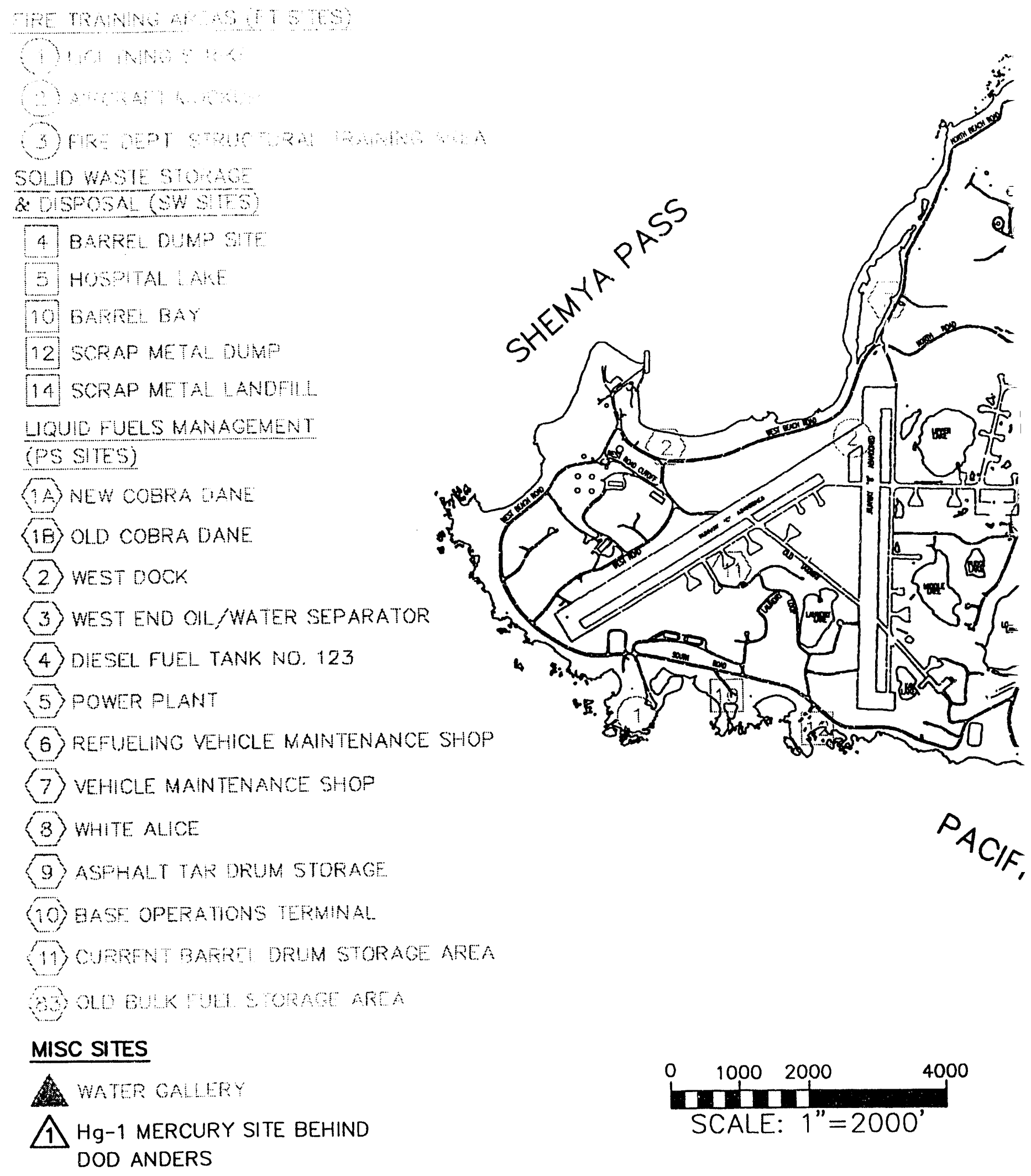

FIGURE 2.3. 22 Sites Incle 


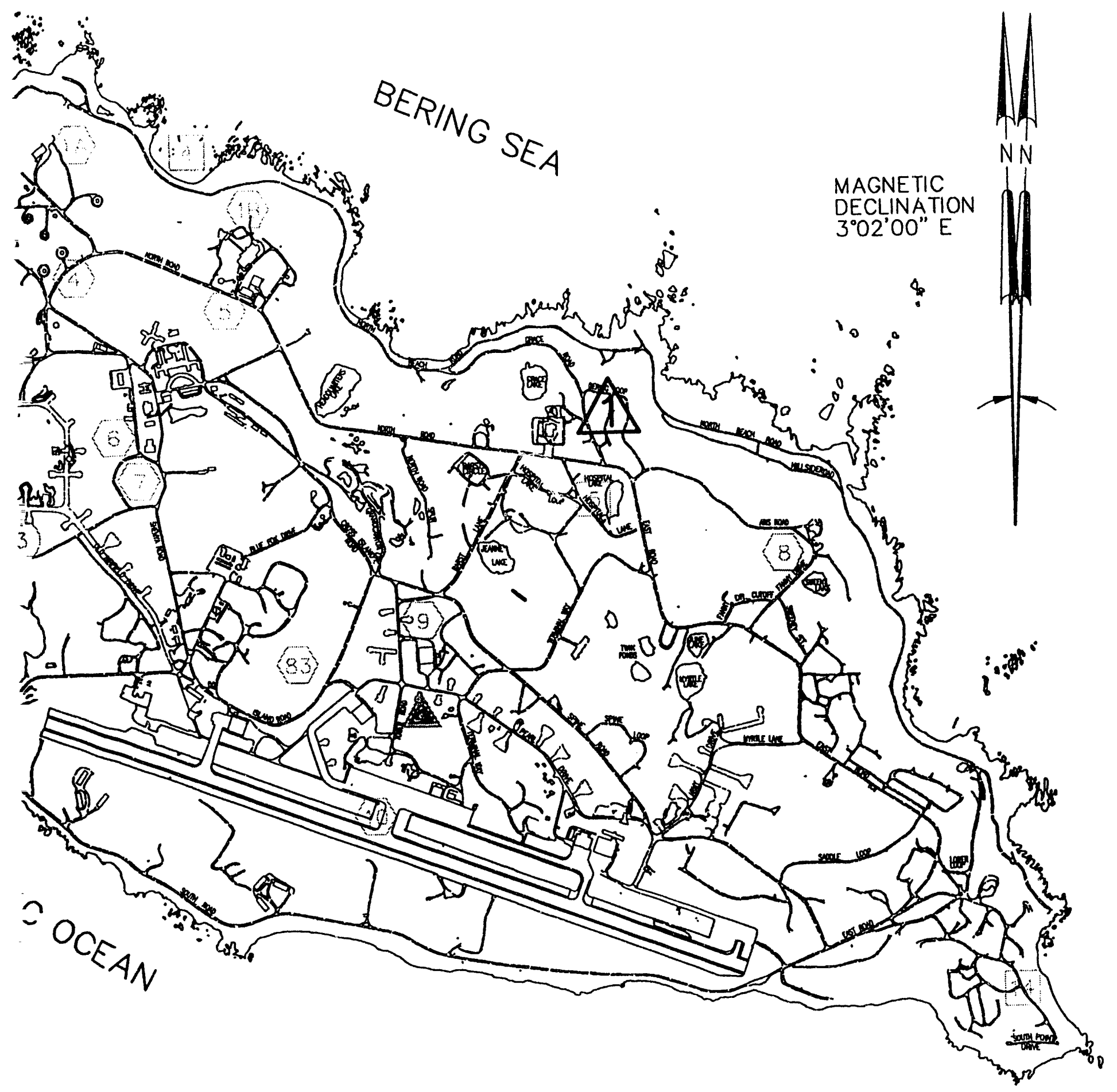

ted in IRP Plan Scope of Work 
The $\mathrm{Hg}-1$ site is located topographically higher than the adjacent sites, and sampling results from the site indicate soil contamination below regulatory levels, as discussed in Section 3. This site has not affected, nor will it be affected by, the adjacent sites.

\subsection{CLIMATOLOGY/METEOROLOGY}

Shemya Island is dominated by a persistent low pressure system referred to as the "Aleutian Low." Frequent storms track across the north Pacific into the Aleutian Islands. The Aleutian Low pressure cells are responsible for the relatively mild maritime climate of the Aleutian Islands. The persistent wind, fog, and salt spray are responsible for the highly corrosive and harsh conditions at Shemya AFB.

\subsubsection{PRECIPITATION}

Average precipitation on Shemya Island is 31.3 inches, and the maximum 24-hour rainfall was recorded as $\mathbf{5 . 2 0}$ inches during October 1962. (a) Precipitation occurs more than 330 days a year. The average annual snowfall is 70 inches, with an average 24-hour snowfall of 3 inches. ${ }^{(a)}$ Drifting snow and driving rain are common because of high wind velocities. The highest precipitation typically occurs in the months of October and November.

\subsubsection{TEMPERATURE}

The mean annual temperature at Shemya AFB is $38.5^{\circ} \mathrm{F}$. (a) The maximum and minimum recorded temperatures are $63^{\circ} \mathrm{F}$ and $7^{\circ} \mathrm{F}$, respectively. The diurnal temperature variation rarely exceeds $10^{\circ} \mathrm{F}$.

\subsubsection{WIND}

The average surface wind speed on Shemya Island is 17 knots. ${ }^{(a)}$ The direction of the wind is evenly distributed, without any true

(a)Becker, 1st Lt. L.J. 1978. The Climatology of Shemya AFB, Aleutian Islands: DET 311 th Weather Squadron, Shemya AFB, AK. Internal Memorandum. 
prevailing wind direction. All months of the year have recorded wind speeds greater than 55 knots.

\subsection{ENVIRONMENTAL SETTING}

\subsubsection{PHYSIOGRAPHY}

Shemya Island is a flat-topped seamount or guyot of the Aleutian volcanic arc in the north Pacific Ocean. The island is rimmed with small gravel beaches and rugged bedrock crags. A small raised beach platform nearly encircles Shemya Island and suggests previous eustatic (sea level) changes. Ground surface is typical of a hummocky glaciated terrain and tundra region. Numerous small ponds are found on the island.

Maximum local relief of the island is $\mathbf{2 7 5}$ feet. Maximum elevations are located on the north side of the island. The topography gently slopes south-southwest to 20 to. 25 feet above the Pacific Ocean.

\subsubsection{GEOLOGY}

\subsubsection{GENERAL GEOLOGY}

Regionally, Shemya Island is part of the Aleutian volcanic arc of the north Pacific Ocean. Shemya Island is composed of a late tertiary volcanic/sedimentary sequence of rocks, bedded pyroclastic rocks, and minor amounts of intrusile rocks, as illustrated in Figure 2.4. Fracturing of the bedrock is intense. Feulner et al. (1976) report that the depth of intense fracturing is approximately 10 feet.

The surficial geology on the island consists of layers of Pleistocene glacial deposits, active and stable eolian deposits, a thin layer of outwash sand and silt, and an extensive layer uf peat. The thickness of the unconsolidated material ranges up to 50 feet (sand dunes). However, in general, the surficial deposits average 5 to 15 feet thick. Unconsolidated material covers nearly all the island. Figure 2.5 illustrates the extent and depths of surficial deposits. Most of the surficial deposits on Shemya Island are capable of retaining and transmitting water. There is no permafrost on Shemya Island. 


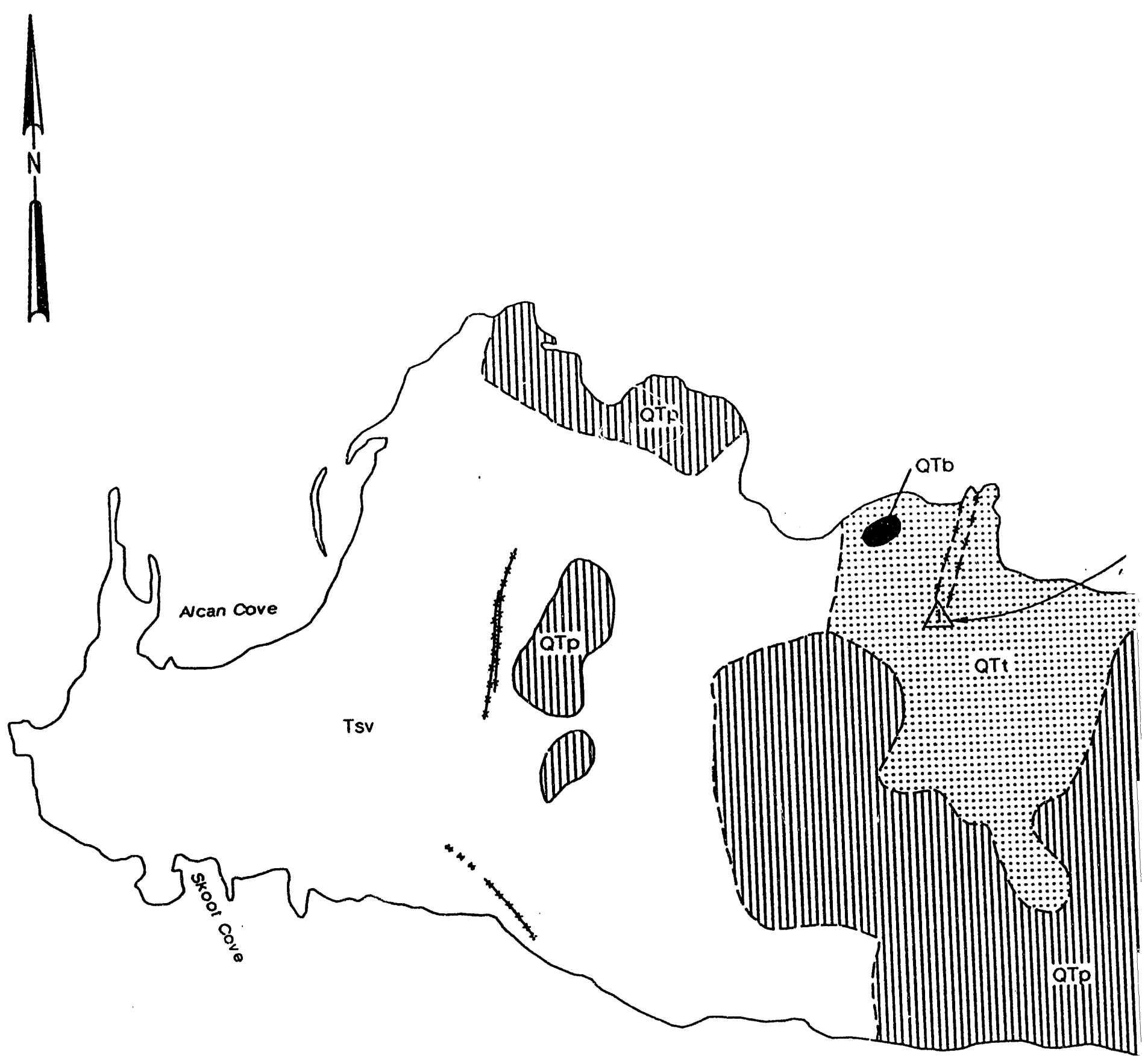

NOTE:
BASE MAP FROM FEULNER et al. 1976

FIGURE 2.4. Bedrock

BO3IS41.RT/EEDROCK2.DWG 


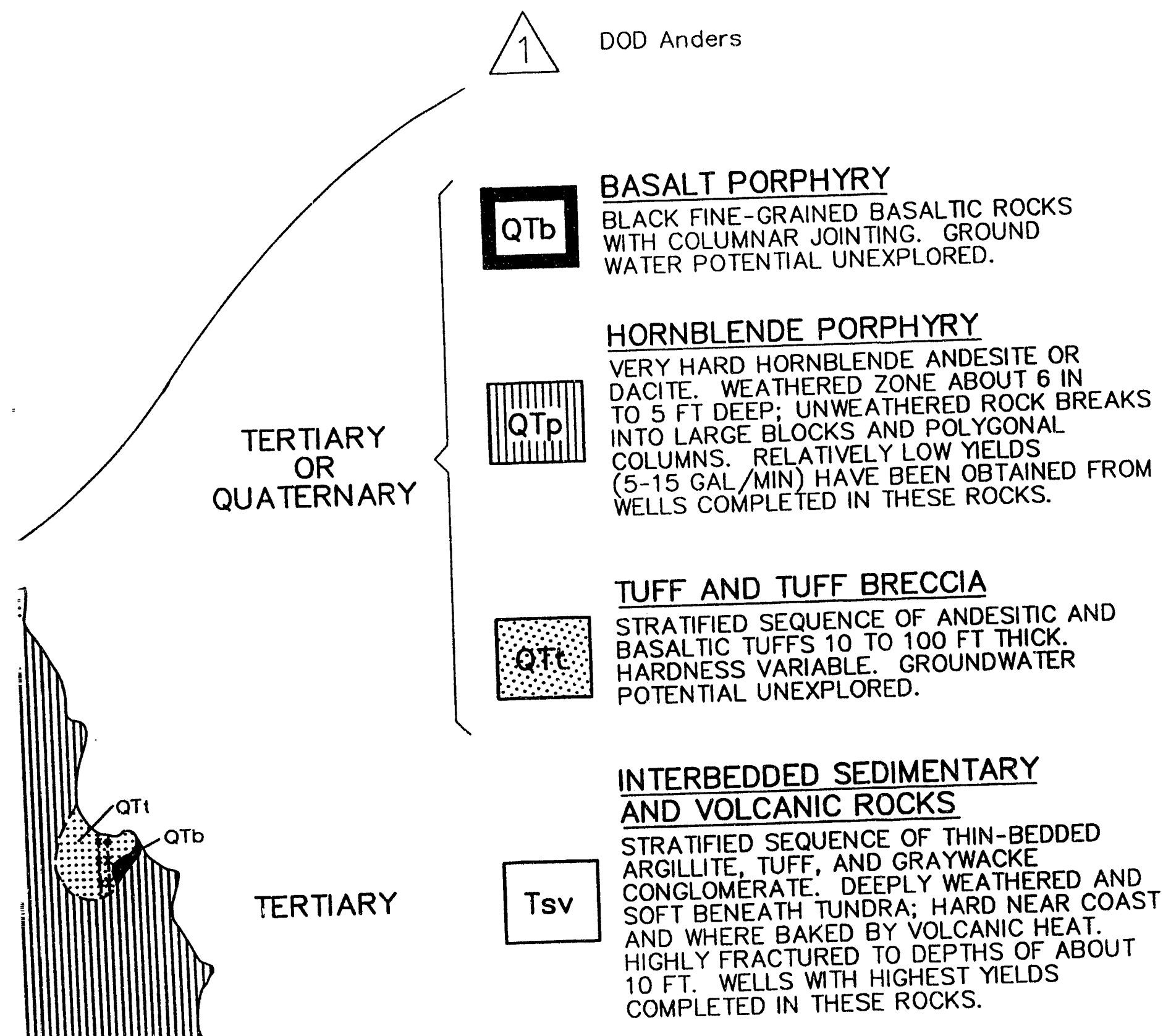

FAULT LINE INFORMATION

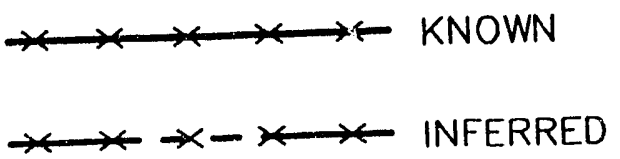





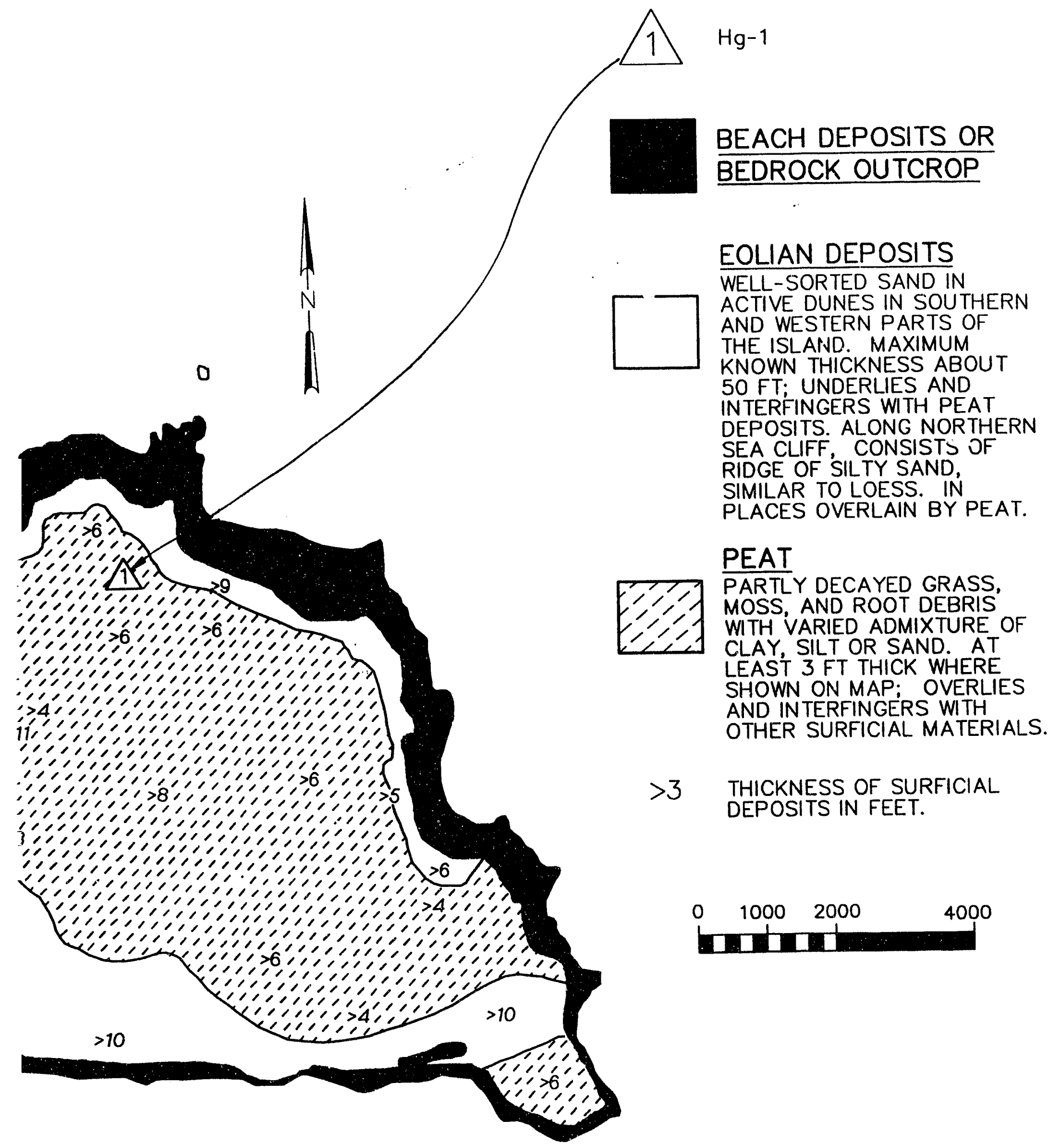


The geology around the $\mathrm{Hg}-1$ site consists of 2 to 3 feet of peat followed by a sand layer extending to approximately 6 feet.

Underlying the sand is bedrock or fractured bedrock consisting of hornblende porphyry and tuff and tuff breccia. 


\subsection{SAMPLE COLLECTION/DATA EVALUATION}

Sampling was performed at $\mathrm{Hg}-1$ in 1987. Background samples were collected in 1987 and 1992 . The results of sampling events are presented below along with an evaluation of the data.

\subsection{BACKGROUND DATA}

Background samples were collected in 1987 and 1992. Results of metals analysis are presented in Table 3.1. Complete analytical results of the 1992 sampling are presented in Appendix B. No analysis for PCBs and dioxin/furans was conducted on 1987 or for dioxin/furans in the 1992 background samples.

Background samples collected during the 1987 sampling event were from areas (near Headquarters Lake and June Lake) that did not appear to be impacted by base activities; however, none were analyzed for mercury. Background sampling for metals, volatile, and semivolatile compounds was conducted in July 1992 as part of the ongoing investigation of the IRP sites. Four background samples were collected from two locations in 1992. BS124 and BS125 were collected from the north slope of the island 100 meters and 40 meters, respectively, upslope from the toe of the slope in the easternmost cove on the north side of the island. BSSD 126 and BSSD 127 were collected just above tide pools in the intertidal zone near to and 200 meters east, respectively, of the active runway.

Mercury analysis of background samples ranged from $<0.11$ to $<0.79 \mathrm{mg} / \mathrm{kg}$ (Appendix B). However, because all background samples were reported as less than detection, no absolute comparison with the sample results for mercury from $\mathrm{Hg}-1$ is possible. The mercury concentrations from the $\mathrm{Hg}-1$ site were within the same range as the background samples.

The 1992 samples were analyzed for PCBs with all results being reported as less than the detection limit (Table 3.1). This indicates that the one positive PCB hit during the 1987 sampling was connected with the area under investigation. 


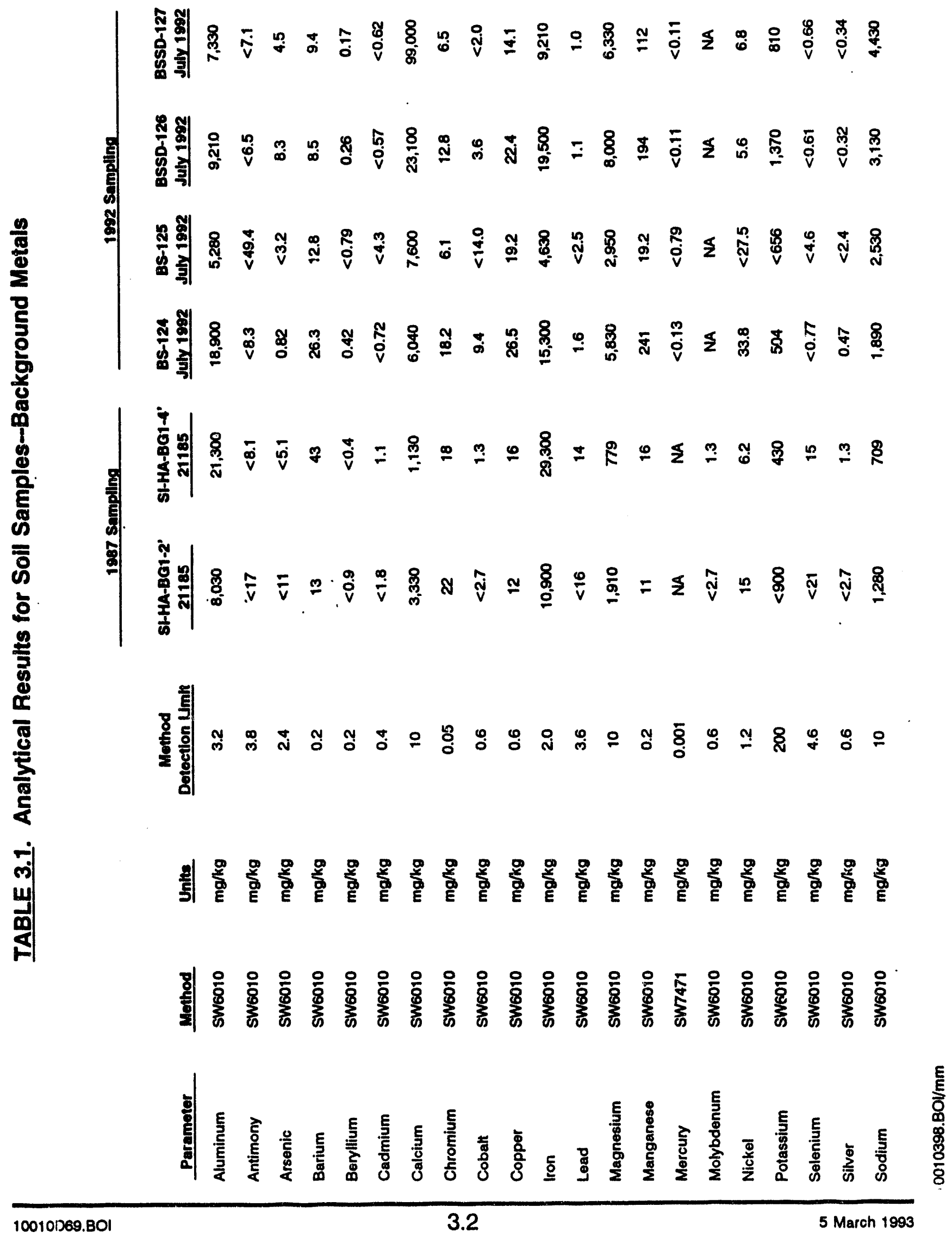




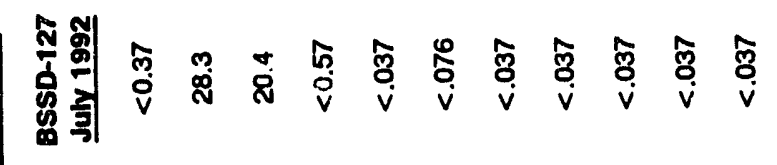

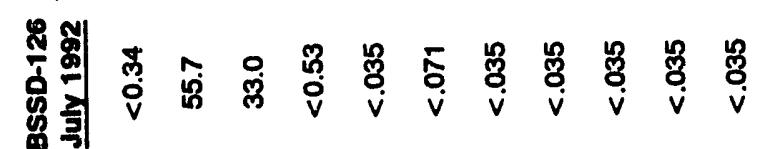

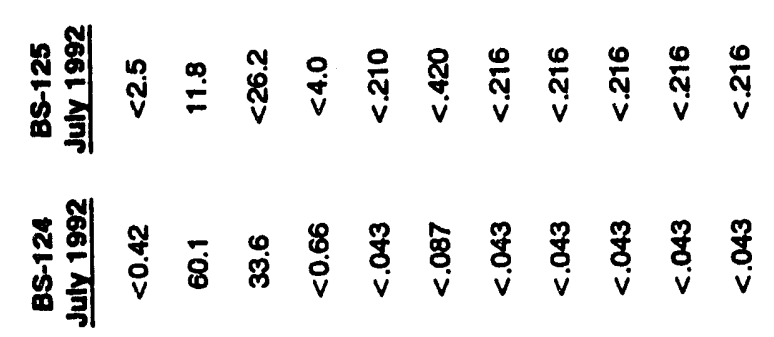

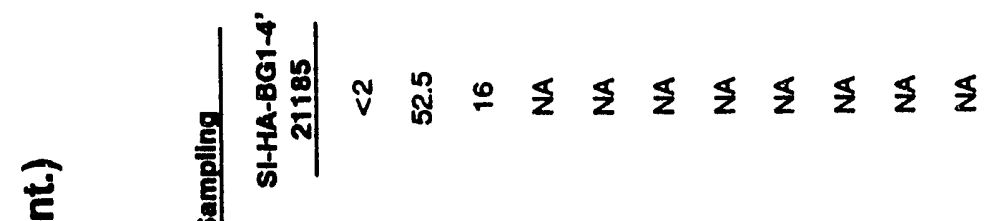

$$
\begin{aligned}
& \text { H } \\
& \text { a) } \\
& \text { 章言 }
\end{aligned}
$$

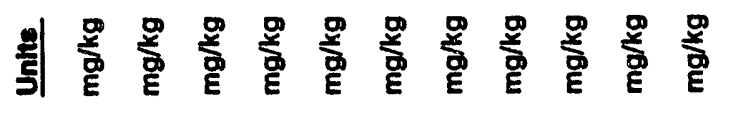

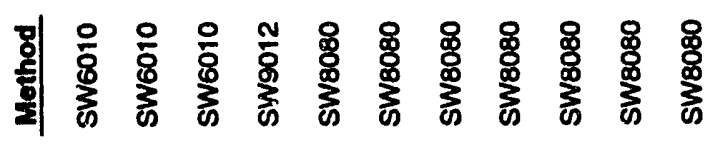

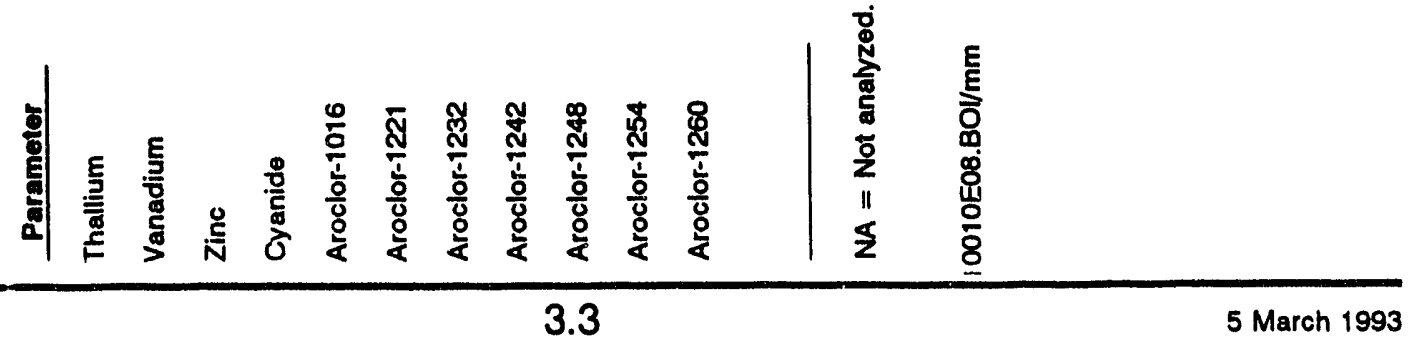




\subsection{SAMPLE COLLECTION}

Sampling was performed in October 1987 east of the current DOD Anders site, near the antenna field. This location was the site of several buildings that have been demolished. Since environmental contamination at this site may have occurred during building demolition, or been a result of mishandling of stored materials, sample locations were placed around the building foundation perimeters, as shown in Figure 3.1. Soil samples were collected from the surface to a depth of 2 feet and represent a composite sample over this depth interval.

\subsection{DATA EVALUATION}

Each sample was analyzed for mercury (SW7471), extraction procedure (EP) toxicity metals (Method 1310), and polychlorinated biphenyl (PCB) compounds (SW8080). One sample was analyzed for dioxin/furans (PCDD/PCDFs SW8280). A summary of the laboratory results is presented in Table 3.2. Also presented are the sample number, units, detection limit, and federal standards for each parameter.

\subsubsection{EP Toxicity Metals}

EP toxicity metals analysis indicates conceritrations at levels below the standards set forth in 40 CFR 261.24.

\subsubsection{Mercury}

Mercury concentrations in the samples ranged from 0.008 to $0.125 \mathrm{mg} / \mathrm{kg}$, which is below the regulatory level of concern of $20 \mathrm{mg} / \mathrm{kg}$ (55 FR 30798). Alaska State Regulation 18 AAC 75.327 requires the cleanup of hazardous substances to background concentrations. Since mercury levels also appear to be within the range of the background concentrations, this site meets the state requirements. 


\section{TABLE 3.2. Laboratory Test Results for Soil}

\begin{tabular}{|c|c|c|c|c|c|c|c|c|c|}
\hline Parameter & Method" & Units & $\begin{array}{c}\text { Detection } \\
\text { Limit }\end{array}$ & $\begin{array}{c}\text { Federal } \\
\text { Standards }\end{array}$ & $\begin{array}{c}1-1 \\
6435-1 \\
\end{array}$ & $\begin{array}{r}2-1 \\
6435-2 \\
\end{array}$ & $\begin{array}{r}2-2 \\
6435-3 \\
\end{array}$ & $\begin{array}{r}2.3 \\
6435-4 \\
\end{array}$ & $\begin{array}{r}3-1 \\
6435-5 \\
\end{array}$ \\
\hline Mercury & SW7471 & $\mathrm{mg} / \mathrm{kg}^{\mathrm{c}}$ & 0.1 & 20 & 0.0960 & 0.0080 & 0.0523 & 0.108 & 0.125 \\
\hline $\begin{array}{l}\text { Arsenic } \\
\text { Barium }\end{array}$ & $\begin{array}{l}S W 7060 \\
E 208.2\end{array}$ & $\mathrm{mg} / \mathrm{L}$ & 0.2 & 100.0 & $<0.5$ & $<0.5$ & $<0.5$ & $<0.5$ & $<0.5$ \\
\hline Cadmium & SW7130 & $\mathrm{mg} / \mathrm{L}$ & 0.005 & 1.0 & 0.042 & 0.028 & 0.022 & 0.023 & 0.021 \\
\hline Chromium & SW7190 & $\mathrm{mg} / \mathrm{L}$ & 0.01 & 5.0 & $<0.05$ & 0.07 & 0.05 & 0.14 & 0.08 \\
\hline Lead & SW7420 & $\mathrm{mg} / \mathrm{L}$ & 0.03 & 5.0 & 0.23 & 0.28 & 0.26 & 0.20 & 0.15 \\
\hline Mercury & SW7470 & $\mathrm{mg} / \mathrm{L}$ & 0.0002 & 0.2 & 0.00205 & 0.00051 & $<0.00010$ & $<0.00010$ & $<0.000$ \\
\hline Selenium & SW7740 & $\mathrm{mg} / \mathrm{L}$ & 0.005 & 1.0 & $<0.005$ & $<0.005$ & $<0.005$ & $<0.005$ & $<0.005$ \\
\hline Silver & SW7660 & $\mathrm{mg} / \mathrm{L}$ & 0.01 & 5.0 & 0.08 & 0.26 & 0.20 & 0.15 & 0.28 \\
\hline $\begin{array}{c}\text { PCBs } \\
1016\end{array}$ & SW8080 & $\mathrm{mg} / \mathrm{kg}^{\mathrm{c}}$ & 0.04 & 10 & $<0.04$ & $<0.04$ & $<0.04$ & $<0.04$ & $<0.04$ \\
\hline 1221 & SW8080 & $\mathrm{mg} / \mathrm{kg}^{\mathrm{c}}$ & 0.04 & 10 & $<0.04$ & $<0.04$ & $<0.04$ & $<0.04$ & $<0.04$ \\
\hline 1232 & SW8080 & $\mathrm{mg} / \mathrm{kg}^{\mathrm{c}}$ & 0.04 & 10 & $<0.04$ & $<0.04$ & $<0.04$ & $<0.04$ & $<0.04$ \\
\hline 1242 & SW8080 & $\mathrm{mg} / \mathrm{kg}^{\mathrm{c}}$ & 0.04 & 10 & $<0.04$ & $<0.04$ & $<0.04$ & $<0.04$ & $<0.04$ \\
\hline 1248 & SW8080 & $\mathrm{mg} / \mathrm{kg}^{\mathrm{c}}$ & 0.02 & 10 & $<0.02$ & $<0.02$ & $<0.02$ & $<0.02$ & $<0.02$ \\
\hline 1254 & SW8080 & $\mathrm{mg} / \mathrm{kg}^{\mathrm{c}}$ & 0.01 & 10 & $<0.01$ & $<0.01$ & $<0.01$ & $<0.01$ & $<0.01$ \\
\hline 1260 & SW8080 & $\mathrm{mg} / \mathrm{kg}^{\mathrm{c}}$ & 0.01 & 10 & $<0.01$ & $<0.01$ & $<0.01$ & $<0.01$ & $<0.01$ \\
\hline $\begin{array}{l}\text { PCDDs and PCDFs } \\
2,3,7,8-T C D D\end{array}$ & SW8280 & $\mu \mathrm{g} / \mathrm{kg}^{\mathrm{f}}$ & 0.17 & & NR & NR & NR & NR & NR \\
\hline $2,3,7,8-\mathrm{TCDF}$ & SW8280 & $\mu \mathrm{g} / \mathrm{kg}$ & 0.11 & & NR & NR & NR & NR & NR \\
\hline
\end{tabular}

${ }^{a}$ SW refers to SW-846, 3rd ed., September 1986.

bActual detection limits may vary based on the sample matrix and operating conditions.

cSamples were analyzed on an as-received basis but calculated to a dry-weight basis.

${ }^{d}$ Detection limit is 10 times higher due to a hydrocarbon background.

'Units are $\mu \mathrm{g} / \mathrm{L}$.

'Samples are reported on an "as received" basis. No correction is made for moisture content.

Note: $N R=$ not requested.

$\mathrm{TR}=$ trip blank. 


\section{amples Area HG-1, Shemya Air Force Base}

Soll Sample Identification/Laboratory Sample ID Number

\begin{tabular}{|c|c|c|c|c|c|c|c|c|c|}
\hline $\begin{array}{c}3-2 \\
6435-7 \\
\end{array}$ & $\begin{array}{c}3-3 \\
6435-8\end{array}$ & $\begin{array}{c}4-1 \\
6435.9\end{array}$ & $\begin{array}{c}5-1 \\
6435-10\end{array}$ & $\begin{array}{c}5-2 \\
6435-11\end{array}$ & $\begin{array}{c}5-3 \\
6435-12\end{array}$ & $\begin{array}{c}6-1 \\
6435.13\end{array}$ & $\begin{array}{c}6-2 \\
6435-14\end{array}$ & $\begin{array}{c}6-3 \\
6435-15\end{array}$ & $\begin{array}{c}\text { TB } \\
6435-16\end{array}$ \\
\hline 0.0692 & 0.0564 & $<0.0115$ & 0.0318 & 0.0564 & 0.0700 & 0.0529 & 0.0528 & 0.0419 & NR \\
\hline$<0.005$ & $<0.005$ & $<0.005$ & $<0.005$ & $<0.005$ & $<0.005$ & $<0.005$ & $<0.005$ & $<0.005$ & NR \\
\hline 0.5 & $<0.5$ & 0.7 & 1.0 & $<0.5$ & 2.7 & $<0.7$ & 1.4 & $<0.5$ & NR \\
\hline 0.015 & $<0.005$ & $<0.005$ & 0.015 & 0.018 & 0.013 & 0.011 & 0.030 & 0.007 & NR \\
\hline 0.06 & 0.05 & $<0.05$ & 0.08 & $<0.08$ & 0.07 & 0.09 & 0.15 & $<0.05$ & NR \\
\hline 0.10 & 0.16 & 0.08 & 0.08 & 0.14 & $<0.05$ & 0.19 & 0.16 & 0.11 & NR \\
\hline$<0.00010$ & $<0.00010$ & $<0.00010$ & $<0.00010$ & 0.00010 & 0.00025 & $<0.00021$ & $<0.00010$ & $<0.0001$ & NR \\
\hline$<0.005$ & $<0.005$ & $<0.005$ & $<0.005$ & $<0.009$ & $<0.011$ & $<0.008$ & 0.006 & $<0.005$ & NR \\
\hline 0.27 & 0.06 & 0.12 & 0.04 & 0.02 & 0.05 & 0.01 & 0.03 & 0.01 & NR \\
\hline$<0.04$ & $<0.04$ & $<0.04$ & $<0.04$ & $<0.04$ & $<0.04$ & $<0.4^{\mathrm{d}}$ & $<0.04$ & $<0.4^{d}$ & $<1^{e}$ \\
\hline$<0.04$ & $<0.04$ & $<0.04$ & $<0.04$ & $<0.04$ & $<0.04$ & $<0.4^{\mathrm{d}}$ & $<0.04$ & $<0.4^{d}$ & $<2^{\mathrm{e}}$ \\
\hline$<0.04$ & $<0.04$ & $<0.04$ & $<0.04$ & $<0.04$ & $<0.04$ & $<0.4^{\mathrm{d}}$ & $<0.04$ & $<0.4^{d}$ & $<2^{\mathrm{e}}$ \\
\hline$<0.04$ & $<0.04$ & $<0.04$ & $<0.04$ & $<0.04$ & $<0.04$ & $<0.4^{\mathrm{d}}$ & $<0.04$ & $<0.4^{d}$ & $<1^{e}$ \\
\hline$<0.02$ & $<0.02$ & $<0.02$ & $<0.02$ & $<0.02$ & $<0.02$ & $0.2^{d}$ & $<0.02$ & $<0.2^{d}$ & $<0.5^{\mathrm{e}}$ \\
\hline$<0.01$ & $<0.01$ & $<0.01$ & $<0.01$ & $<0.01$ & $<0.01$ & $<0.1^{d}$ & $<0.01$ & $<0.1^{d}$ & $<0.2^{e}$ \\
\hline$<0.01$ & $<0.01$ & $<0.01$ & $<0.01$ & $<0.01$ & $<0.01$ & $<0.1^{d}$ & $<0.01$ & $<0.1^{d}$ & $<0.2^{\mathrm{e}}$ \\
\hline NR & NR & NR & NR & NR & NR & $<0.051$ & NR & NR & NR \\
\hline NR & NR & NR & NR & NR & NR & $<0.043$ & NR & NR & NR \\
\hline
\end{tabular}




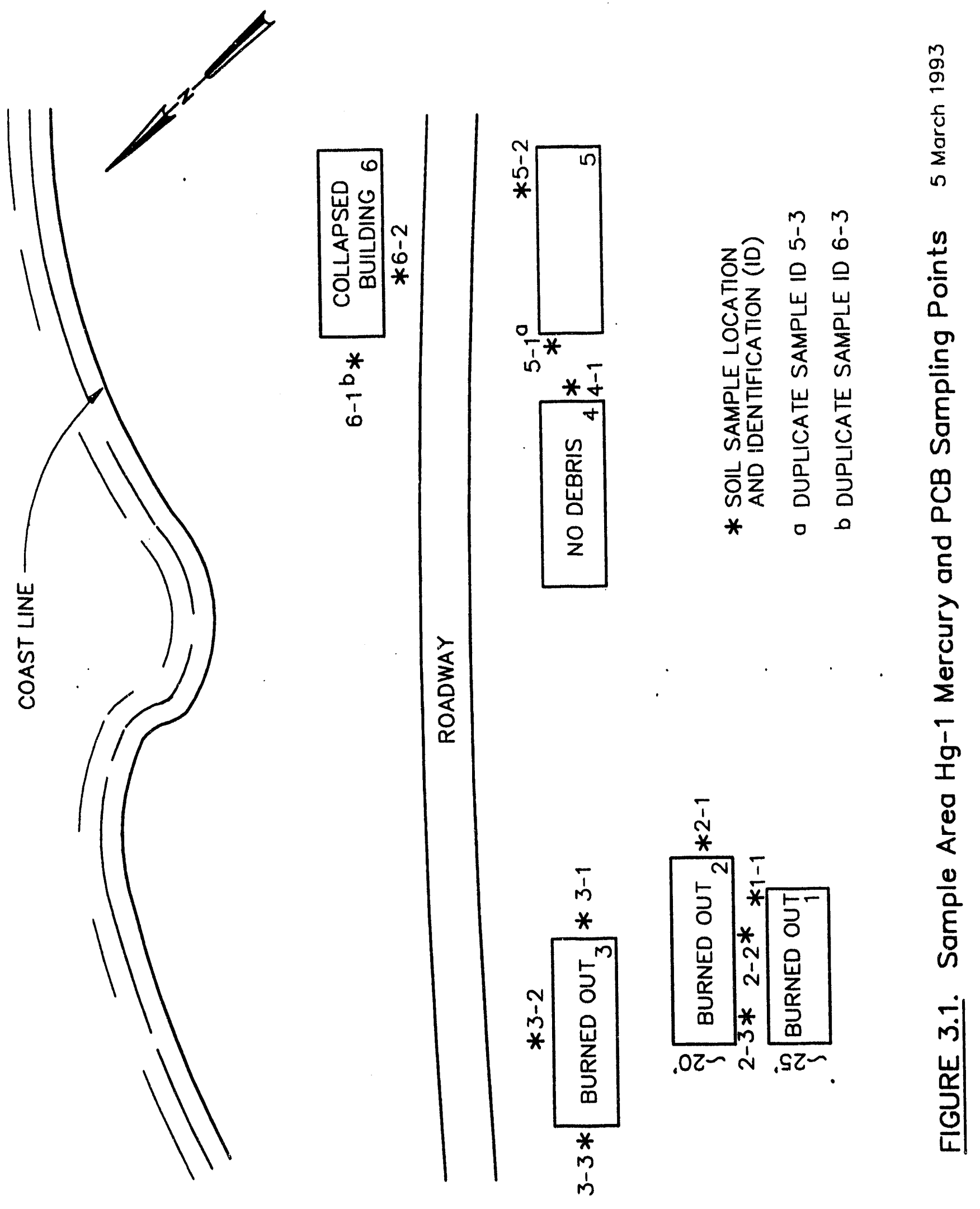




\subsubsection{PCBs}

A detection for PCB 1248 was reported at $0.2 \mathrm{mg} / \mathrm{kg}$ at location 6-1 near Building 6 . This concentration is less than the $10 \mathrm{ppm}$ minimum concentration for removal indicated in 40 CFR 761. Alaska Solid Waste Regulation 18 AAC 60.075 allows landspreading waste containing up to $10 \mathrm{mg} / \mathrm{kg}$ PCB. All other analysis results were below detection limits (background).

\subsubsection{Dioxin/Furans}

Dioxin/furans testing performed at this location did not report constituents above the method detection limit.

\subsection{QA/QC}

Complete analytical results for the sampling events are provided in Appendix $A$, including QA $Q C$ laboratory sample results. No data were flagged or rejected for QAVC reasons. Samples were handled and transported under proper chain-of-custody procedures, and all sampling procedures specified in the work plans were followed. 


\subsection{EXPOSURE ROUTES}

An exposure pathway is the means by which a person (receptor) may come into contact with (be exposed to) chemical contaminants in environmental media. A complete pathway has five elements:

- source of contamination

- mechanisms for contaminant release

- environmental transport medium

- exposure point

- feasible route of exposure.

If one of these five elements does not exist, the exposure pathway is incomplete and exposure will not occur and there is no risk of adverse health effects.

Analysis of samples collected from this site indicates that:

- PCBs are below the level of regulatory concern

- mercury is within or lower than the background concentration range and below the level of regulatory concern

- dioxins/furans are below detection levels.

Therefore, exposure routes are not presented because there is no indication of constituents to be transportated to a receptor through these routes. 
As discussed earlier, levels of mercury, PCBs, and dioxin are below regulatory levels of action and/or detection limits. Consequently, there are no constituents at levels that would adversely affect any of the following receptors.

\subsection{HUMAN}

\subsection{ANIMAL}

On Shemya Island, the human receptors of environmentallyreleased contaminants are the 700 military and civilian service personnel stationed on the island. This population can increase to approximately 1,000 individuals during the summer.

The exposure scenario at this site involves the potential exposure of construction workers to contaminants found. The assessment of this scenario follows the standard EPA guidance for a commercial/industrial worker scenario of a 20-year exposure (EPA, 1989). This scenario was chosen because it is more conservative than a scenario involving base personnel or a trespasser on the isiand. The base personnel are on the island only one year compared to a possible 15 to 20 years for a construction worker.

The only endangered land animal ever known to have inhabited Shemya is the Aleutian Canada goose (Branta canadensis leucopareia), which is indigenous to the Aleutian Islands of the north Pacific. The intentional introduction of the blue phase Arctic fox (Alopex lagopus) by fur farmers between the 1830s and 1930s proved to be detrimental to the Aleutian Canada goose and was responsible for their extinction on Shemya Island. No Aleutian Canada geese were found nesting on Shemya Island, nor are they expected to nest there unless the Arctic blue fox is eliminated from the island. Therefore, at this time, there is no impact to this endangered species.

\subsection{AQUATIC}

Several species of sea mammals use the rocky coastline of Shemya Island, predominantly seals and sea lions. Whales and porpoises also use the waters around the island. However, no known nesting or spawning grounds are within the immediate 
area. There are no commercial fisheries in the surface waters of Shemya Island. However, commercial fishing does occur in the ocean around the island.

\subsection{PLANT}

Vegetation on Shemya Island consists primarily of various grasses, lichens, and mosses. Much of the land surface is covered with peat and meadow types of vegetation. Seaweeds are common along the rocky shore and reef areas of the island. The only trees on the island are those on the western side of Hospital Lake. There are no endangered plant species on Shemya Island. 


\subsection{RISK ASSESSMENT}

Because the concentrations of the contaminants of concern were below regulatory action levels or background concentrations, the exposure pathway was incomplete and exposure will not occur and there is no risk of adverse health effects. However, comparison of these concentrations to action levels is presented below.

Polychlorinated biphenyl compounds were detected in one soil sample at the Hg-1 IRP site (Table 3.2) at concentrations lower than the action levels specified in the Toxic Substances Control Act (TSCA) (40 CFR 761). These regulations apply to soil, rags, or other debris contaminated with PCBs as well as spills or leaks involving PCBs. PCB 1248 was measured at $0.2 \mathrm{mg} / \mathrm{kg}$. The EPA PCB spill cleanup policy, a part of TSCA (40 CFR 761 Subpart G) for nonrestricted access areas, is:

"Soil contaminated by the spill will be decontaminated to $10 \mathrm{ppm}$ PCBs by weight provided that soil is excavated to a minimum depth of 10 inches. The excavated soil will be replaced with clean soil, i.e., containing less than 1.ppm PCBs and the spill site will be restored (e.g., replacement of turf)."

Since the concentrations of $\mathrm{PCB}$ in soil at the $\mathrm{Hg}-1$ site are less than $10 \mathrm{ppm}$ and, in fact, are less than the definition of "clean soil" stated above, no further remedial actions resulting from PCB contamination are planned for the $\mathrm{Hg}-1$ site. In addition, the PCB levels in these near-surface samples are less than the levels specified under 18 AAC 60.075 for land spreading.

Soil concentrations of dioxins are below detection levels. Soil concentrations of mercury are above detection levels, but less than the regulatory level of concern of $20 \mathrm{mg} / \mathrm{kg}$ (Table 3.2) (55 FR 30798), and below the range of mercury concentrations in background soil samples as required by 18 AAC 75.327. Therefore, no remedial actions are planned based on dioxins or mercury levels. 


\subsection{REFERENCES}

Alaska Administrative Code (AAC). "Solid Waste Management Regulations." 18 AAC 60.

Alaska Administrative Code (AAC). "Oil and Hazardous Substances Pollution Control Regulations." 18 AAC 75.

40 CFR 261.24. "Identification and Listing of Hazardous Waste." U.S. Code of Federal Regulations.

40 CFR 761. Environmental Protection Agency, "Polychlorinated Biphenyls (PCBs) Manufacturing, Processing, Distribution in Commerce, and Use Prohibitions." U.S. Code of Federal Regulations.

55 FR 30798. July 27, 1990. Environmental Protection Agency, "Corrective Action for Solid Waste Management Units at Hazardous Waste Management Facilities; Proposed Rule." Federal Register.

Feulner, A. J., C. Zenone, and K. M. Reed. 1976. Geohydrology and Water Supply, Shemya Island, AK. U.S. Geological Survey, open-file map report 76-82.

Ross, Cpt. J. L., 1969. Construction and Operation of a World War II Army Air Force Forward Base: Shemya AK. May 1943December 1945. Office of History, Alaskan Air Command, 80 p.

U.S. Environmental Protection Agency (EPA). 1989. Risk Assessment Guidance for Superfund: Volume 1 - Human Health Evaluation Manual (Part A). Publication EPA/540/1-89/002. December 1989. 
Appendix A

Laboratory Results for Sample Area Hg-1 
Table G-1B

SOIL SAMPLE IDENTIFICATION CROSS-REFERENCE

Field

Number

HG-1-1-1

HG-1-2-1

HG-1-2-2

HG-1-2-3

HG-1-3-1

$H G-1-3-2$

HG $-1-3-3$

HG-1-4-1

HG-1-5-1

HG-1-5-2

HG $-1-5-3$

HG-1-6-1

HG $-1-6-2$

HG $-1-6-3$

HG-1-Trip

Blank

$057 a: G 1: 2$
Iab Number

Sample Description

Page

Gravel to 1", dark brown soil

(porous). water at $1.7^{\prime}$

RDD 18418-1

$\begin{array}{ll}\text { CVO } 6435-2 & \text { Fine grey sand to black with } \\ \text { RDD 18418-2 } & \text { white deposits, water at } 4^{n}\end{array}$

CVO $6435-3$

Gravel to $3 / 8^{\prime \prime}$, medium coarse

brown soil with brown decayed tundra

CVO 6435-4. RDD 18418-4

Coarse gravel to $3 / 8^{\prime \prime}$, hit water and tundra (light tan) material at $1.5^{\prime}$

Greyish, black sand, decayed tundra $14^{\prime \prime}-16^{\prime \prime}$, water at $1.5^{\prime}$

RDD 18418-5

Coarse gravel to $3 / 8^{\prime \prime}=6^{\prime \prime}-8^{\prime \prime}, 8^{\prime \prime}-18^{\prime \prime}$

medium fine soil, dark brown to

black sand $18^{\prime \prime}-20^{\prime \prime}$

RDD 18418-7

CVO 6435-8

ROD 18418-8

Very coarse gravelisample to $15^{\mathrm{N}}$

CVo 6435-9

RDD 18418-9

very sandy, water at 7', dark

brown clay soils $18^{n}$

CVo 6435-10

Dark greyish brown sand

RDD 18418-10

CVO 6435-11 RDD 18418-11

Dark grey sand, water at 3"

CVO 6435-12

RDD 18418-12

Dark greyish brown sand

Duplicate of $\mathrm{KG}-1-5-1$

CVo 6435-13

RDD 18418-13

ENSECO 32272

Dark grey sand

CVO 6435-14

RDD 18418-14

CVO 6435-15

RDD 18418-15

Coarse gravel (brown)

Dark grey sand

Duplicate of HG-1-6-1

CVo 6435-6 Water

RDD 18418-6 
Environmental Laboratory

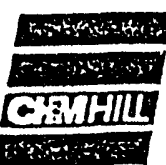

Engineers

Planners

Economists

Scientists

CIIENT:
Date: December 23, 1987

Project No: : K24155.AO

Page 1 of:2

SUBJECT: Analysis of 14 soil samples received October 19,1987, and assigned Laboratory Reference Number 6435 .

\section{Parameter}

EP Toxicity, as $\mathrm{mg} / \mathrm{L}$

Arsenic, As

Barium, Ba

Cadmium, Cä

Chromium, Cr

Lead, $\mathrm{Pb}$

Mercury, Hg

Selenium, Se

Silver, Ag

Mercury, Hg, as $\mathrm{mg} / \mathrm{kg}^{\mathrm{a}}$

\section{Parameter}

EP Toxicity, as $\mathrm{mg} / \mathrm{L}$

Arsenic, As

Barium, Ba

Cadrium, Cd

Chromium, $\mathrm{Cr}$

Lead, $\mathrm{Pb}$

Mercury, Hg

Selenium, Se

Silver, Ag
Mercury, Hg, as $\mathrm{mg} / \mathrm{kg}^{\mathrm{a}}$

\begin{tabular}{|c|c|c|c|}
\hline $\begin{array}{c}\text { HG }-1-1-1 \\
6435-1\end{array}$ & $\begin{array}{c}8 G-1-2-1 \\
6435-2 \\
\end{array}$ & $\begin{array}{c}\text { GG-1-2-2 } \\
6435-3 \\
\end{array}$ & $\begin{array}{c}\text { HG }-1-2-3 \\
6435-4 \\
\end{array}$ \\
\hline $\begin{array}{l}<0.005 \\
<0.5 \\
0.042 \\
<0.05 \\
0.23 \\
0.00205 \\
<0.005 \\
0.08 \\
0.0960\end{array}$ & $\begin{array}{l}<0.005 \\
<0.5 \\
0.028 \\
0.07 \\
0.28 \\
0.00051 \\
<0.005 \\
0.26 \\
0.0080\end{array}$ & $\begin{array}{l}<0.005 \\
<0.5 \\
0.022 \\
0.05 \\
0.26 \\
<0.00010 \\
<0.005 \\
0.20 \\
0.0523\end{array}$ & $\begin{array}{l}<0.005 \\
<0.5 \\
0.23 \\
0.14 \\
0.20 \\
<0.00010 \\
<0.005 \\
0.15 \\
0.108\end{array}$ \\
\hline
\end{tabular}

EG-1-3-1 BG-1-3-2 BG-1-3-3 BG-1-4-1 $6435-5$ 6435-7 6435-8 6435-9

$\begin{array}{llll}<0.005 & <0.005 & <0.005 & <0.005 \\ <0.5 & 0.5 & <0.5 & 0.7 \\ 0.021 & 0.015 & <0.005 & <0.005 \\ 0.08 & 0.06 & 0.05 & <0.05 \\ 0.15 & 0.10 & 0.16 & 0.08 \\ <0.00010 & <0.00010 & <0.00010 & <0.00010 \\ <0.005 & <0.005 & <0.005 & <0.005 \\ 0.28 & 0.27 & 0.06 & 0.12 \\ 0.125 & 0.0692 & 0.0564 & <0.0115\end{array}$




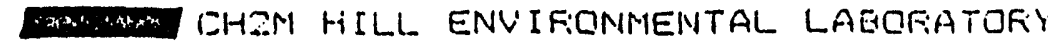

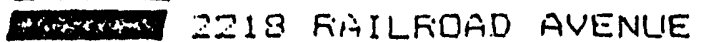

CIITIII FIEDUING, CA $9 O 001$

$910-245-58 \div 1$

oficin

FEFAFIT TE:

SHEMYA AFE

CHIM HILL/CVO

$\because 24155 \cdot A 0$

ATTENTION: JOHN MAFTTINSEN

SAMFLE DESCFIIFTICIN: SOIL

DATE OF SAMFLE: $1 \% 113 / 67$
REFEFIENCE NUMEEF: $\quad 184.18$

FAGE 1 OF 4

DATE: $11: \because / 87 \quad \because:$

FHONE:

SFMFLED EY: Fi. TFEEGLE/E. FALIGHT

DATE FECEIVED: $10 / 20 / 87$

TEST METHODS: EFA-OOOB-BOB०

$$
\begin{array}{cccccc}
H G- & H G- & H G- & H G- & H G- & H G- \\
1-1-1 & 1-2-1 & 1-2-2 & 1-2-3 & 1-3-1 & 1-3-2
\end{array}
$$

CONST I TUENT

6455-1 6435-2 S4:5-3 64J5-4 S455-5 64J5-7

PCE-1221

PCE-12E2

PCE -1242

PCE -1015

FCB -1248

FCE -1254

FCE 1260

$\begin{array}{llllll}<0.04 & 50.04 & 50.04 & <0.04 & <0.04 & <0.04 \\ <0.04 & <0.04 & 50.04 & 60.04 & <0.04 & <0.04 \\ <0.04 & <0.04 & 50.04 & <0.04 & <0.04 & <0.04 \\ <0.04 & <0.04 & <0.04 & <0.04 & <0.04 & <0.04 \\ <0.02 & <0.02 & 50.02 & <0.02 & <0.02 & <0.02 \\ <0.01 & 50.01 & 50.01 & <0.01 & <0.01 & <0.01 \\ <0.01 & <0.01 & <0.01 & <0.01 & <0.01 & <0.01\end{array}$

ext $10 / 20$

and $10 / 2$ ?

COMMENTS: Results in milligrams per kilogram

The information shown on this sheet is test data only and no analysis or interpretation is intended or implied.

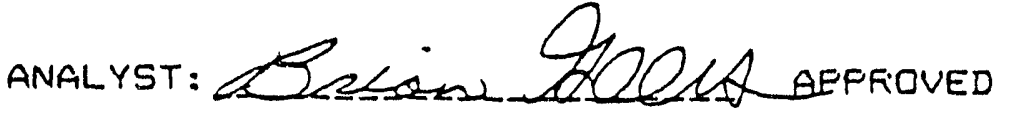

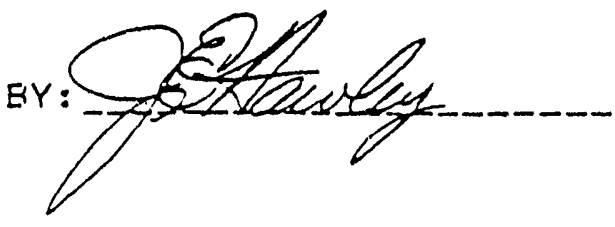


REFOFT TO:

SHEMYA AFE

CHIM HILL/CVO

K24155. AO

ATTENTION: JOHN MAFTINSEN

SAMFLE DESCRIFTION: SOIL

DATE OF SAMFLE: $10 / 16 / 87$
FEFEFENCE NUMEEF: 18418

FAGE 2 OF 4

DATE: $11 / \mathrm{E} / 97$

FHONE:

SAMFLED EY: R. TREEBLEIE. FAUGHT DATE RECEIVED: $10 / 20 / 37$

TEST METHODS: EFA-608-8080

$$
\begin{array}{cccccc}
H G- & H G- & H G- & H G- & H G- & H G- \\
1-3-3 & 1-4-1 & 1-5-1 & 1-5-2 & 1-5-5 & 1-6-1
\end{array}
$$

\begin{tabular}{|c|c|c|c|c|c|c|}
\hline CONST I TUENT & $435-8$ & $6455-9$ & $0455-10$ & $54.5-11$ & $6435-12$ & $6435-15$ \\
\hline $\begin{array}{l}F C B-1221 \\
P C B-1232 \\
F C B-1242 \\
F C B-1016 \\
F C B-1248 \\
P C E-1254 \\
P C B-1260\end{array}$ & $\begin{array}{l}<0.04 \\
<0.04 \\
<0.04 \\
<0.04 \\
<0.02 \\
<0.01 \\
<0.01\end{array}$ & $\begin{array}{l}<0.04 \\
<0.04 \\
<0.04 \\
<0.04 \\
<0.02 \\
<0.01 \\
<0.01\end{array}$ & $\begin{array}{l}<0.04 \\
<0.04 \\
50.04 \\
50.04 \\
<0.02 \\
<0.01 \\
60.01\end{array}$ & $\begin{array}{l}<0.04 \\
50.04 \\
50.04 \\
50.04 \\
50.02 \\
50.01 \\
50.01\end{array}$ & $\begin{array}{l}60.04 \\
60.04 \\
60.04 \\
60.04 \\
60.02 \\
60.01 \\
60.01\end{array}$ & $\begin{array}{l}50.4 \\
60.4 \\
50.4 \\
<0.4 \\
0.2 \\
60.1 \\
60.1\end{array}$ \\
\hline
\end{tabular}

$$
\begin{aligned}
\text { ext } & 10 / 20 \\
\text { ded } & -10 / 29-9-12 \\
- & 10 / 30-13 \\
\text { redal }-11 / 2 & -13
\end{aligned}
$$

COMMENTS: Results in milligrams per kilogram

Sample HG-1-6-1 had a ten times higher detection limit due to a hydrocarbon background.

The information shown on this sheet is test data only and no analysis or interpretation is intended or implied.

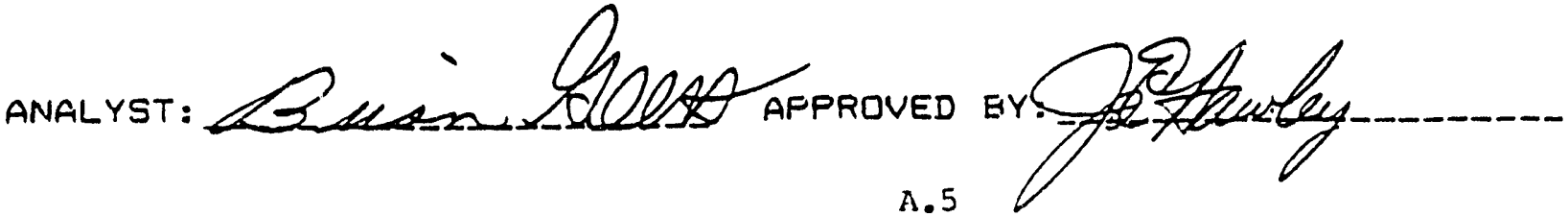


FEFOFT TO:

SHEMYA AFE

CHIM HILL/CVO.

K24155.AO

ATTENTION: JOHN MAFTINSEN SAMFLE DESCFIFTION: SOIL DATE OF SAMFLE: $10 / 16 / 87$
FEFERENCE NUMEEF: 18418

FAGE $:$ OF 4

DATE: $11 / 3 / 87$

FHONE:

SAMFLLED EY: FI. TREEELE/E. FAUGHT DATE RECEIVED: $10 / 20 / 97$

TEST METHODS: EFA-608-80180

$$
\begin{array}{ll}
H G- & H G- \\
1-6-2 & 1-6-3
\end{array}
$$

CONST I TUENT

FCE-12:1

FCE -1232

PCE-1242

FCE-1016

FCB-1248

PCE- 1254

FCE-1260

$6435-14$ 6455-15

$\begin{array}{ll}<0.04 & <0.4 \\ <0.04 & <0.4 \\ 50.04 & 50.4 \\ <0.04 & <0.4 \\ <0.02 & <0.2 \\ 50.01 & <0.1 \\ 50.01 & <0.1\end{array}$

ext $10 / 30$
sub. $11 / 2$

COMMENTS: Results in milligrams per kilogram

Sample HG-1-6-3 had a ten times higher detection limit due to a hydrocarbon background.

The information shown on this sheet is test data only and no analysis or interpretation is intended or implied.

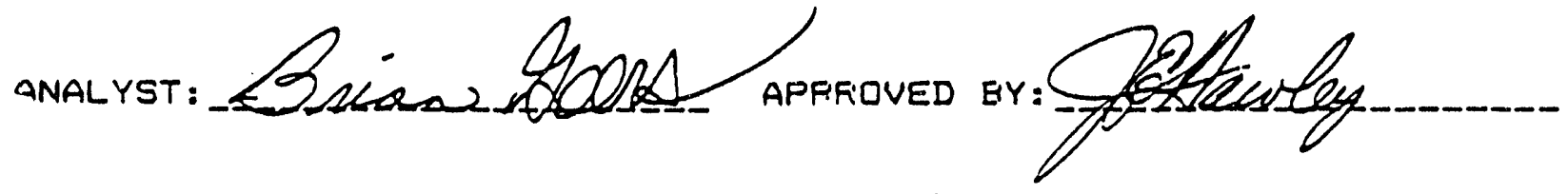


CHIM HILL ENVIFIONMENTAL LAEOFATOFY 2213 T:AILFIJAD AVENUE

FEFOFIT TO:

SHEITYA AFE

CHIM HILL/CVO K24155. AC:

ATTENTION: JOHN MAFITINSEN SAMFLE DEGCFIFTION: WATEF DATE OF SAMFILE: $10 / 16 / 87$
REFEFENCE NUMEEF: 18418

F.AGE 4 OF 4

DATE: $11,5 / 87$

FHONE:

SAMFLED EY: $\dot{R}$. TREEELE/E. FAUGHT DATE RECEIVED: $\quad 10 / 20 / 87$

TEST METHODS: EFA-608-8080

HG-

1-TRIF

CONST I TUENT

ELANK:

PCE-1221

FCE-1232

FCE-1242

FCB-1016

FCE-1248

PCB-1254

PCB-1260)
$<2$

$<2$

$<1$

$<1$

$<0.5$

$<0.2$

<0. 2

$$
\begin{aligned}
& \text { ext } 10 / 22 \\
& \text { ad. 10/30 }
\end{aligned}
$$

COMMENTS: Results in micrograms per liter

The information shown on this sheet is test data only and no analysis or interpretation is intended or implied.

anAlyst: 2 Megnt

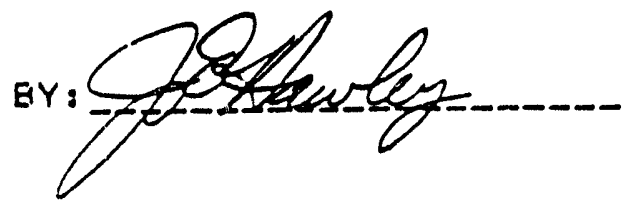




\section{Enseco}

November 24,1987

Lab IO: 32272

Brian Geers

CH2M Hill

P.0. Box 2088

2218 Rall road Avenue

Redding, CA 96001
REPORT TO: ShemYa AFB

CH2M HILL/CVO

Attn: John Martinsen

Sample ID: HG-1-6-1 6435-13

Dear Mr. Geer:

Enclosed is the report for the one soil sample for your SAFB Project which was received at Enseco-Cal Lab on 12 November 1987.

The report consists of the following sections:

\section{Sample Description \\ II Analysis Request \\ III Quality Control Report \\ IV Analysis Results}

No problems were encountered with the analysis of your samples.

If you have any questions, please feel free to call.

sincerely,

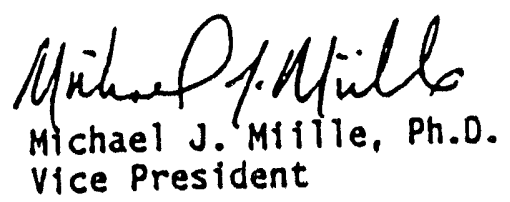

ka 
I Sample Description

$\frac{\text { Lab } 10}{32272} \frac{\text { Client } 10}{\text { Soil } 18418-12}$ Matrix $\frac{\text { Oate Sampled }}{11-\text { Nov-87 }} \frac{\text { Containers }}{16 \text { oz Jar }}$

The sample was received under chain-of-custody.

\section{Analysis Request}

The following analytical test was requested.

$\frac{\text { Lab ID }}{32272} \quad \frac{\text { Analysis Description }}{2,3,7,8-T C D O / T C D F}$

\section{Quality Control}

B. Method Blank Results. A method blank is a laboratory-generated sample which assesses the degree to which laboratory operations and procedures cause false-positive analytical results for your samples.

No target parameters were detected in the method blanks associated with your samples at the reporting limit levels noted on the data sheets in the Analytical Results section.

C. Laboratory Control Samples. An LCS is a well-characterized matrix (blank water; sand or celite) which is spiked with certain target parameters and analyzed at approximately $10 \%$ of the sample load in order to establish method-specific control limits. The LCS results associated with your samples follow:

Test: Dioxin Solids LCS

LCS ID: 8280301087

Concentration Units: ng

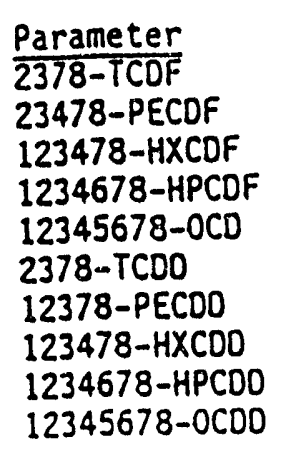

\begin{tabular}{c} 
Spike \\
\hline 10 \\
10 \\
10 \\
10 \\
50 \\
10 \\
10 \\
10 \\
10 \\
50
\end{tabular}

Concentration

$$
\text { Measured }
$$

LCS1 LCS2

11.3

9.1

15.3

12.5

65.5

11.9

10.9

14.6

10.7

47.5
11.7

9.2

14.2

13.1

64.0

11.3

11.2

14.0

10.2

50.0

\begin{tabular}{c}
\hline \\
\hline LCS \\
\hline 113 \\
91 \\
153 \\
125 \\
131 \\
119 \\
109 \\
146 \\
107 \\
95
\end{tabular}

Accuracy Accover $\frac{\mathrm{LCS} 2}{117} \frac{\mathrm{AV}}{115}$ 92 142 131 128

113

112

140

102

100

\begin{tabular}{|c|c|}
\hline Av. & Limits \\
\hline 115 & $N C$ \\
\hline 92 & NC \\
\hline 148 & NC \\
\hline 128 & NC \\
\hline 130 & NC \\
\hline 116 & NC \\
\hline 111 & NC \\
\hline 143 & NC \\
\hline 105 & NC \\
\hline 98 & $N C$ \\
\hline
\end{tabular}

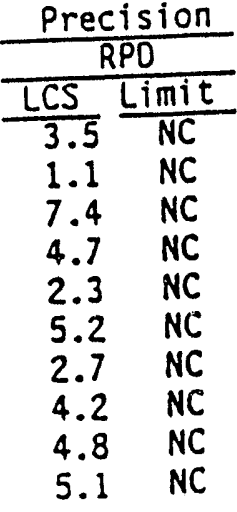




\section{LOW RESOLUTION}

Client Name: CH2H Hill

Client 10: So il \#18418-12 HG-1-6-1 6435-13

Lab 10: 32272-001

Matrix: Soil

Enseco 10: NA

Sampled: 11-Nov-87 Received: 12-Nov-87

Prepared: 12-Nov-87 Analyzed: 18-Nov-87

Authorized: 12-Nov-87

Sample Amount: $10.01 \mathrm{~g}$

Column Tyoe: SP-2331

Parameter

Result Units $\begin{gathered}\text { Detection } \\ \text { Limit }\end{gathered}$

Furans

$2,3,7,8-$ TCDF

ND

$n g / g$

0.043

Dioxins

$2,3,7,8-T C D O$

ND

$n g / g$

0.051

$37 \mathrm{Cl}-2,3,7,8-\mathrm{TCOO}$

E Accuracy

103

NA

\% Recovery

NA

$13 \mathrm{C}-2,3,7,8-\mathrm{TCOO}$

39

$N D=$ Not Detected

$N A=$ Not Applicable

Reported by: AFS

Approved by: 20

The cover letter is an integral part of this report.

Version 070187

A. 10 
$2,3,7,8-\mathrm{TCDO} / \mathrm{TCDF}$

LOH RESOLUTION

Client Name: CH2M Hill

Client I0: Method 8 lank

Lab 10: 32272-MB

Matrix: Soil

Authorized: NA

Sample Amount: $10.02 \mathrm{~g}$

Column Trpe: SP-233I

Parameter

Furans

$2,3,7,8-T C D F$

Dioxins

$2,3,7,8-T C D O$

$37 \mathrm{C1}-2,3,7,8-\mathrm{TCDO}$

$13 ?-2,3,7,8-T C D O$
Received: NA.

Enseco 10: NA Sampled: NA

Prepared: 12-Nov-87

Analyzed: 18-Nov-87
Result Units $\begin{gathered}\text { Detection } \\ \text { Limit }\end{gathered}$

ND

$n g / g$

0.061

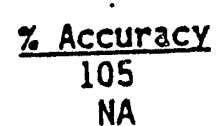

NA
\% Recovery

NA

39

$N D=$ Not Detected

$N A=$ Not Applicable

Reported by: AFS

Approved by: Of

The cover letter is an integral part of this report.

Version 0701:37

A. 11 
Accuracy is measured by Percent Recovery as in:

$\therefore$ recovery $=\frac{\text { (measured concentration) }}{\text { (actual concentration) }} \times 100$

Precision is measured using duplicate tests by Relative Percent Difference (RPD) as in:

$$
\text { RPD }=\frac{(\% \text { recovery test } 1-\% \text { recovery test } 2)}{(\% \text { recovery test } 1+\% \text { recovery test } 2) / 2} \times 100
$$

Control limits for accuracy (percent recovery) are based on the average, historical percent recovery $+/-3$ standard deviation units. Control limits for precision (relative percent difference) range from 0 (identical duplicate LCS results) to the average, historical relative percent difference +3 standard deviation units. These control limits are updated on a quarterly basis.

\section{Analysis Results}

Test methods prefaced by "Enseco" indicate that minor modifications of jublished EPA Methods were made such as reporting limits or parameter lists. Reporting limits are adjusted. to reflect dilution of the sample, when appropriate. Solid and waste samples are reported on an "as received" basis; i.e., no correction is made for moisture content. All data is "blank corrected" by subtracting the level of contamination, if any, found in the laboratory method blank from the analytical result before it is reported.

Results are on the attached data sheets. 
Environmental Laboratory Date: December 23, 1987 Project No: K24155.AO Page 2 of 2

\section{Parameter}

EP Toxicity, as $\mathrm{mg} / \mathrm{L}$

Arsenic, As

Barium, Ba

Cadmium, Ca.

Chromium, $\mathrm{Cr}$

Lead, $\mathrm{Pb}$

Mercury, Hg

Selenium, Se

Silver, Ag

Mercury, Hg, as $\mathrm{mg} / \mathrm{kg}^{2}$

Parameter

EP Toxicity, as $\mathrm{mg} / \mathrm{L}$

Arsenic, As

Barium, Ba

Cadmium, Cd

Chromium, Cr

Lead, $\mathrm{Pb}$

Mercury, Hg

Selenium, Se

Silver, Ag

Mercury, Hg, as $\mathrm{mg} / \mathrm{kg}^{2}$
HG-1-5-1 HG-1-5-2 HG-1-5-3 HG-1-6-1

$6435-10$ 6435-11 6435-12 6435-13

$<0.005$
1.0
0.015
0.08
0.08
$<0.00010$
$<0.005$
0.04
0.0318

$<0.005$

$<0.5$

0.018

0.08

0.14

$<0.00010$

0.009

0.02

0.0564

$<0.005$
2.7
0.013
0.07
$<0.05$
0.00025
0.011
0.05
0.0700

$<0.005$

0.7

0.011

0.09

0.19

0.00021

0.008

0.01

0.0259

$$
\begin{aligned}
& \text { HG-1-6-2 HG-1-6-3 } \\
& \text { 6435-14 6435-15 }
\end{aligned}
$$

$<0.005<0.005$

$1.4<0.5$

$0.030 \quad 0.007$

$0.15<0.05$

$0.16 \quad 0.11$

$<0.00010<0.00010$

$0.006<0.005$

$0.03 \quad 0.01$

$0.0528 \quad 0.0419$

${ }^{a}$ Mercury was analyzed on an as-received basis but calculated to a dry-weight basis.

<Means less than.

Analyses performed in accordance with methods approved by the OSEPA. Samples will be retained 30 days unless otherwise requested. The information shown on this sheet is test data only and no interpretation is intended or implied.

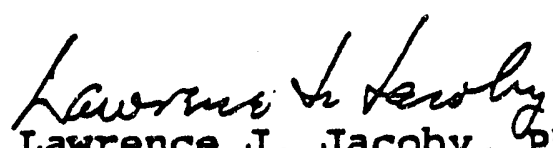

Lawrence J. Jacoby, $\mathcal{P h}_{\text {.D }}$

Environmental Laboratory Manager

$R B: R J$ 


\section{Appendix B \\ Laboratory Results for Background Samples \\ Collected in July 1992}


U.S. CLP

1

INORGANIC ANALYSIS DATA SHEET

Lab Name: CALIFORNIA ANALYTICAL LAB Contract:

SAS NO.:

Lab Sample ID: $65147-20$

Date Received: $07 / 28 / 92$

Level (low/med): LOW
CLIENT SAMPLE NO.

BS -124

SDG NO.: BS-124 lab Code: ENSECO Project No.: 65147

75.3

Concentration Units (ug/L or mg/kg dry weight): MG/KG

CAS No.
$\frac{7429-90-5}{\frac{7440-36-0}{740-38-2}}$
$\frac{7440-39-3}{740-41-7}$
$\frac{740-43-9}{7440-70-2}$
$\frac{7440-48-4}{740-50-8}$
$\frac{7439-89-6}{\frac{7439-92-1}{7439-96-5}}$
$\frac{7439-97-6}{\frac{7440-02-0}{7440-09-7}}$
$\frac{7482-49-2}{7440-22-4}$
$\frac{7440-23-5}{7440-62-2}$
$\frac{740-66-6}{736}$

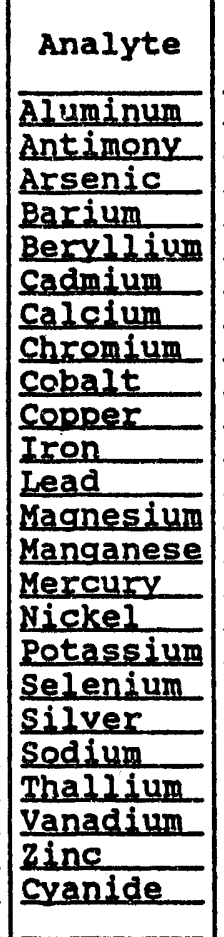

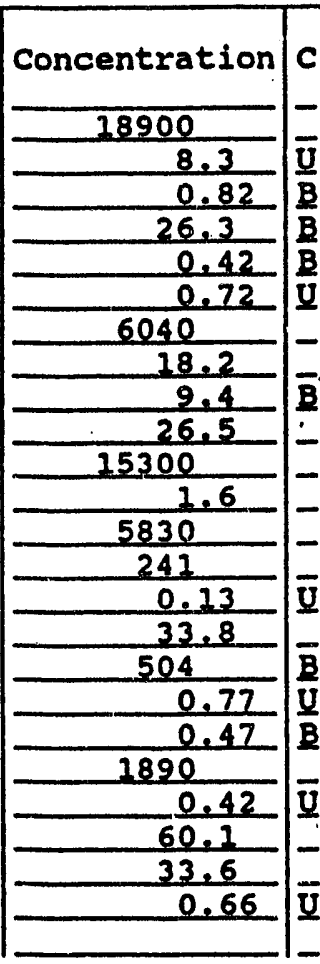
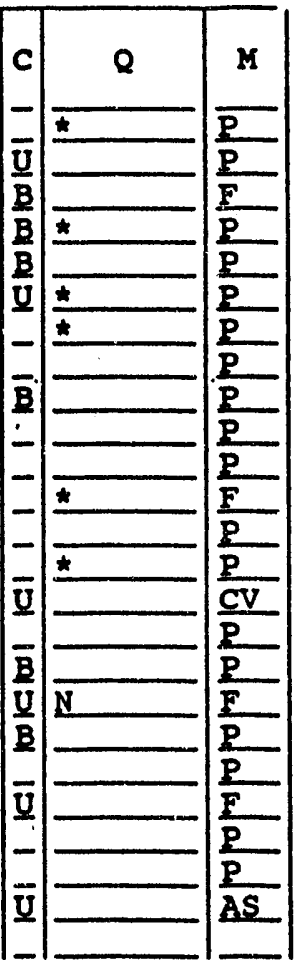

Color Before: BROWN

Clarity Before:

Texture: MEDIUY Color After: BROWN

Artifacts:

Comments: 
U.S. CLP

1

INORGANIC ANALYSIS DATA SHEET

Lab Name: CALIFORNIA ANALYTICAC LAB Contract:

Lab Code: ENSECO Project No.: 65147 SAS No.:

Matrix (soil/water): SOIL

Level (low/med): LOW

12.6

Concentration Units (ug/L or $\mathrm{mg} / \mathrm{kg}$ dry weight) : KG/KG

\begin{tabular}{|c|c|c|c|c|c|}
\hline CAS No. & Analyte & concentration & C & $\mathbf{Q}$ & $\mathbf{M}$ \\
\hline $2429-90-5$ & Auminum & 5280 & & \pm & $P$ \\
\hline $7440-36-0$ & Antimony & 49.4 & $\underline{\mathbf{U}}$ & & $p$ \\
\hline $7440-38-2$ & Arsenic & 3.2 & $\underline{\mathbf{U}}$ & & 5 \\
\hline $7440-39-3$ & Barjum & 12.8 & B & $\star$ & $P$ \\
\hline $2440-41-7$ & Beryl1jum & 0.79 & $\underline{\mathbf{U}}$ & & $P$ \\
\hline $7440-43-9$ & Cadmium & 4.3 & $\mathbf{I}$ & $\star$ & $P$ \\
\hline $7440-70-2$ & Calcium & 7600 & 8 & $\star$ & $\mathbf{P}$ \\
\hline $7440-47-3$ & Chromium & $\div 6$ & B & 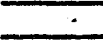 & $p$ \\
\hline $7440-48-4$ & eobalt & 14 & I & & $P$ \\
\hline $7440-50-8$ & Copper & 19.2 & $\mathbf{B}$ & & $\mathbf{p}$ \\
\hline $7439-89-6$ & Iron & 4630 & & & $p$ \\
\hline $7439-92-1$ & Iead & 2.5 & $\overline{\mathbf{u}}$ & 中W & $E$ \\
\hline $7439-95-4$ & Magnesium & 2950 & $\underline{\mathbf{B}}$ & & $p$ \\
\hline $7439-96-5$ & Manganese & 19 & $\overline{\mathbf{B}}$ & $\star$ & $p$ \\
\hline $7439-97-6$ & Mercury & 0.79 & $\overline{\mathrm{U}}$ & & cV \\
\hline $7440-02-0$ & Nickel & 27.5 & U & & $p$ \\
\hline $7440-09-7$ & Potassium & 656 & $\overrightarrow{\mathrm{U}}$ & & $p$ \\
\hline $7782-49-2$ & Selenium & 4.6 & $\overline{\mathrm{U}}$ & $\mathbf{N}$ & $E$ \\
\hline $7440-22-4$ & Silver & 2.4 & I & & $p$ \\
\hline $7440-23-5$ & Sodium & 2530 & $\mathrm{~B}$ & & $\mathrm{p}$ \\
\hline $7440-28-0$ & Thallium & 2.5 & ti & & $E$ \\
\hline $2440-62-2$ & Vanadium & 11,8 & B & & $P$ \\
\hline $7440-66-6$ & Zinc & 26,2 & II & & $p$ \\
\hline & Cyanide & 4.0 & $\underline{\mathbf{v}}$ & & AS \\
\hline
\end{tabular}

Color Before: BROWN

Color After: BROWN

Clarity Before:

clarity After:

Texture:

Artifacts:
CLIENT SAMPLE NO.

BS -125

SDG NO.: BS-124

Lab Sample ID: 65147-21

Date Received: $07 / 28 / 92$

\section{Comments :}

FORM I - IN

$3 / 90$

B. 2 


\section{U.S. CLP}

1

INORGANIC ANALYSIS DATA SHEET
CLIENT SAMPLE NO.

BSSD -126

SDG NO.: $\mathrm{BS}-124$
Lab code: ENSECO Project No.: 65147 SAS No.: '

Matrix (soil/water): soIr.

Level (low/med): LOW
Lab Sample ID: $65147-22$

Date Received: $07 / 28 / 92$

solids:

95.0

Concentration Units (ug/L or $\mathrm{mg} / \mathrm{kg}$ dry weight): MG/KG

\begin{tabular}{|c|c|c|c|c|c|}
\hline CAS No. & Analyte & Concentration & c & $\mathbf{Q}$ & $\mathbf{M}$ \\
\hline $7429-90-5$ & ATuminum & 9210 & -1 & 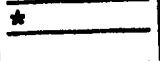 & $\frac{p}{p}$ \\
\hline $7440-36-0$ & Antimony & 6.5 & $\underline{\mathbf{u}}$ & & $\frac{p}{F}$ \\
\hline $7440-38-2$ & Arsenic & $\frac{8.3}{0.5}$ & & $\frac{5}{\star}$ & $\frac{L}{P}$ \\
\hline $7440-39-3$ & Barium & $\frac{8.5}{0.5}$ & $\frac{\mathbf{B}}{\mathbf{B}}$ & & $p$ \\
\hline$\frac{7440-41-7}{7440-43-9}$ & & $\begin{array}{r}0.26 \\
0.57 \\
\end{array}$ & $\frac{\mathbf{B}}{\mathbf{U}}$ & $\star$ & 2 \\
\hline$\frac{7440-43-9}{7440-70-2}$ & $\frac{\text { Cadmium }}{\text { calcium }}$ & 23100 & - & \pm & P \\
\hline$\frac{7440-70-2}{7440-47-3}$ & Chromium & 12.8 & -1 & & P \\
\hline$\frac{7440-47-3}{7440-48-4}$ & Cobalt & 3.6 & B & & $\mathbf{P}$ \\
\hline $2440-50-8$ & Copper & 22.4 & -1 & & $p$ \\
\hline $7439-89-6$ & Iron & 19500 & - & & p \\
\hline $7439-92-1$ & Iead & 1.1 & - & $\star S$ & $E$ \\
\hline $7439-95-4$ & Magnesium & 8000 & - & & ? \\
\hline $7439-96-5$ & Manganese & 194 & & $\star$ & $P$ \\
\hline $7439-97-6$ & Mercury & 0.11 & प्u & - & CV \\
\hline 2440-02-0 & Nickel & 5.6 & B & & $\frac{P}{P}$ \\
\hline $7440-09-7$ & Potassium & 1370 & $=1$ & & $p$ \\
\hline $7782-49-2$ & Selenium & 0.61 & $\underline{\mathrm{U}}$ & $\mathbf{N}$ & $F$ \\
\hline $7440-22-4$ & silver & 0.32 & $\underline{\mathbf{U}}$ & & $P$ \\
\hline $7440-23-5$ & Sodium & 3130 & $=$ & & $P$ \\
\hline $7440-28-0$ & Thallium & 0.34 & U & W & $\frac{F}{p}$ \\
\hline$\frac{7440-62-2}{7440-66-6}$ & $\frac{\text { Vanadium }}{\text { Tinc }}$ & $\begin{array}{l}55.7 \\
33.0\end{array}$ & - & & $\mathbf{p}$ \\
\hline $1440-00-0$ & cyanide & 0.53 & $\overline{\mathbf{u}}$ & & AS \\
\hline
\end{tabular}

Color Before: BROWN color After: BROWN clarity Before: Clarity After:
Texture: MEDIUY Artifacts:

\section{Comments :}

FORM I - IN

$3 / 90$

B. 3 
U.S. CLP

1

INORGANIC ANALYSIS DATA SHEET

Lab Name: CALIFORNIA ANALXTICAL LAB Contract:

Lab Code: ENSECO Project No.: 65147

SAS NO.:

Lab Sample ID: $65147-23$

Date Received: $07 / 28 / 92$

Level (Low/med): LOW
CLIENT SAMPLE NO.

BSSD-127

SDG NO.: BS-124.

t Solids: $\quad 87.5$

Concentration Units (ug/L or $\mathrm{mg} / \mathrm{kg}$ dry weight): MG/KG

\begin{tabular}{|c|c|c|c|c|c|}
\hline CAS NO. & Analyte & Concentration & c & Q & $M$ \\
\hline $7429-90-5$ & Aluminum & 7330 & 3 & \pm & $\bar{P}$ \\
\hline $7440-36-0$ & Antimony & 7.1 & $\overline{\mathbf{v}}$ & & $p$ \\
\hline $7440-38-2$ & Arsenic & 4.5 & & & \\
\hline $7440-39-3$ & Barium & 9.4 & $\mathbf{B}$ & $\star$ & P \\
\hline $7440-41-7$ & Berylifium & 0.17 & $\overline{\mathbf{B}}$ & & R \\
\hline $7440-43-9$ & cadmium & 0.62 & $\mathbf{\underline { \mathbf { U } }}$ & & p \\
\hline $7440-70-2$ & calcium & 99000 & - & 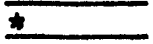 & $p$ \\
\hline $7440-47-3$ & chromium & 6.5 & & & ? \\
\hline $7440-48-4$ & Cobalt & 2.0 & $\underline{\mathbf{v}}$ & & $\bar{P}$ \\
\hline $7440-50-8$ & Copper & 14.1 & - & & P \\
\hline $7439-89-6$ & Iron & 9210 & - & & R \\
\hline $7439-92-1$ & Lead & 1.0 & $=$ & 호 & $E$ \\
\hline $7439-95-4$ & Magnesium & 6330 & $z$ & & 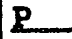 \\
\hline $7439-96-5$ & Manganese & 212 & & $\star$ & $\mathbf{p}$ \\
\hline $7439-97-6$ & Mercury & 0.11 & $\underline{\mathbf{u}}$ & & CV \\
\hline $7440-02-0$ & Nickel & 6.8 & $\overline{\mathbf{B}}$ & & P \\
\hline $7440-09-7$ & Potassium & 810 & $\overline{\mathbf{B}}$ & & $\underline{p}$ \\
\hline $7782-49-2$ & Selenium & 0.66 & $\overline{\mathbf{u}}$ & NW & $E$ \\
\hline $7440-22-4$ & Silver & 0.34 & $\bar{v}$ & & P \\
\hline $7440-23-5$ & Sodium & 4430 & & & $p$ \\
\hline $7440-28-0$ & Thaldium & 0.37 & $\mathbf{Q}$ & & $E$ \\
\hline $7440-62-2$ & Vanadium & 28.3 & - & & $P$ \\
\hline $7440-66-6$ & $\frac{\text { zinc }}{\text { cyanide }}$ & $\frac{20.4}{0.57}$ & $\overline{\mathrm{v}}$ & & $\frac{P}{A S}$ \\
\hline & cranzae & & 2 & & \\
\hline
\end{tabular}

Color Before: BROWN Color After: BROWN

comments:
Clarity Before: Clarity After:
Texture: MaDIUN Artifacts: 
18

SEMIVOLATILE ORGANICS ANALYSIS DATA SHEET

Lab Name: ENSECO

Lab Code: ECAL

Case No.: 65147

Contract:

SAS No.:

Matrix: (soil/water) SOIL

Sample wt/vol: $\quad 30.0(\mathrm{~g} / \mathrm{mL}) \mathrm{G}$

Level: (low/med) LoW

\% Moisture: 23 decanted: $(Y / N) N$

Concentrated Extract Volume: 500.0 (UL)

Injection Volume: $\quad 2.0(u L)$

(uL) Date Analyzed: 08/13/92

GPC Cleanup: $\quad(Y / N) Y$

$\mathrm{pH}: \quad 6.0$

Lab Sample ID: 65147-20

Lab File ID: 6514720RI

Date Received: 07/28/92

Date Extracted: 07/30/92

Dilution Factor: 1.0
EPA SAMPLE NO.

BS - 124

SDG No.: BS-124

CONCENTRATION UNITS:

(ug/L or $u g / K g$ ) UG/KG $Q$

\begin{tabular}{|c|c|c|}
\hline 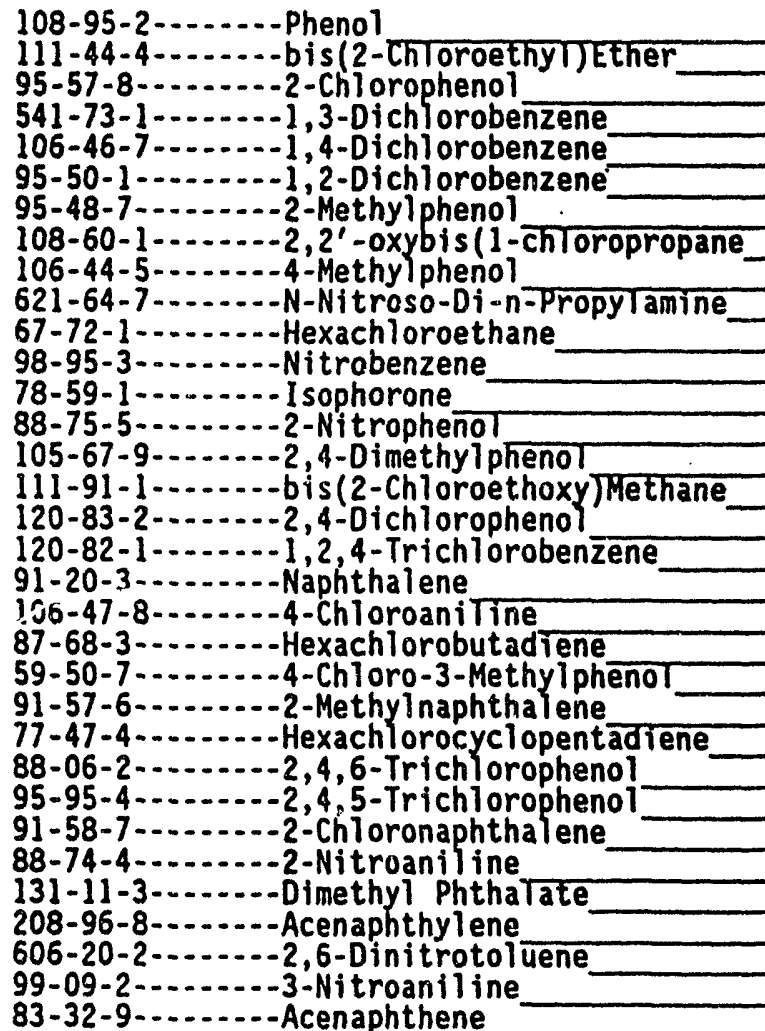 & $\begin{array}{r}430 \\
430 \\
430 \\
430 \\
430 \\
430 \\
430 \\
430 \\
430 \\
430 \\
430 \\
430 \\
430 \\
430 \\
430 \\
430 \\
430 \\
430 \\
430 \\
430 \\
430 \\
430 \\
430 \\
430 \\
430 \\
1000 \\
430 \\
1000 \\
430 \\
430 \\
430 \\
1000 \\
430\end{array}$ & $\begin{array}{l}U \\
U \\
U \\
U \\
U \\
U \\
U \\
U \\
U \\
U \\
U \\
U \\
U \\
U \\
U \\
U \\
U \\
U \\
U \\
U \\
U \\
U \\
U \\
U \\
U \\
U\end{array}$ \\
\hline
\end{tabular}


IC

SEMIVOLATILE ORGANICS ANALYSIS DATA SHEET

Lab Name: ENSECO

Lab Code: ECAL

Case No.: 65147

Matrix: (soil/water) SOIL

Sample wt/vol:

$30.0(\mathrm{~g} / \mathrm{mL}) \mathrm{G}$

Level: (low/med) LOW

* Moisture: 23 decanted: $(Y / N) N$ Concentrated Extract Volume: 500.0 (UL) Injection Volume:$$
2.0(u L)
$$

GPC Cleanup: $\quad(Y / N) Y \quad$ pH: $\mathbf{6 . 0}$

CAS NO.
Contract:

SAS No.:
EPA SAMPLE NO.

BS-124

SDG No.: BS-124

Lab Sample ID: 65147-20

Lab File ID: $6514720 R I$

Date Received: 07/28/92

Date Extracted: $07 / 30 / 92$

Date Analyzed: 08/13/92

Dilution Factor: 1.0

\begin{tabular}{|c|c|c|}
\hline 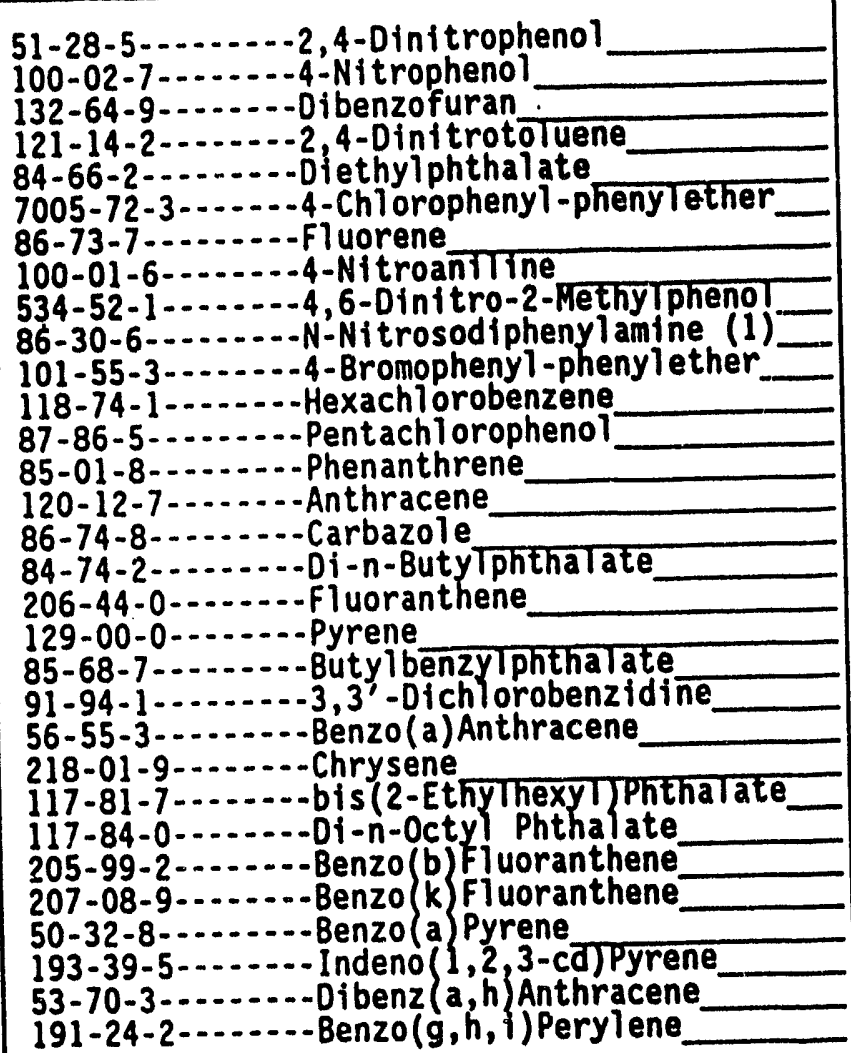 & $\begin{array}{r}1000 \\
1000 \\
430 \\
430 \\
430 \\
430 \\
430 \\
1000 \\
1000 \\
430 \\
430 \\
430 \\
1000 \\
430 \\
430 \\
430 \\
430 \\
430 \\
430 \\
430 \\
430 \\
430 \\
430 \\
80 \\
430 \\
430 \\
430 \\
430 \\
430 \\
430 \\
430\end{array}$ & $\begin{array}{l}U \\
U \\
U \\
U \\
U \\
U \\
U \\
U \\
U \\
U \\
U \\
U \\
U \\
U \\
U \\
U \\
U \\
U \\
U \\
U \\
U \\
U \\
U \\
U \\
U \\
U \\
U \\
U \\
U \\
B J \\
U \\
U \\
U \\
U \\
U \\
U \\
U \\
U\end{array}$ \\
\hline
\end{tabular}

FORM I SV-2 
$1 F$

SEMIVOLATILE ORGANICS ANALYSIS DATA SHEET

TENTATIVELY IDENTIFIED COMPOUNDS

Lab Name: ENSECO

Contract:

Case No.: 65147 SAS No.:

Lab Code: ECAL

Matrix: (soil/water) SOIL

Sample wt/vol:

$30.0(g / m L) G$

Level: (low/med) LOW

* Moisture: 23 decanted: (Y/N) N

Concentrated Extract Volume: 500.0

(uL)

Injection Volume:

2.0(UL)

GPC Cleanup: $(Y / N) Y$

$\mathrm{pH}: \quad \mathbf{6 . 0}$
EPA SAMPLE NO.

BS - 124

SDG No.: BS-124

Lab Sample ID: 65147-20

Lab F1le ID: 6514720RI

Date Received: 07/20;92

Date Extracted: 07/30/92

Date Analyzed: 08/13/92

Dilution Factor: 1.0

Number TICs found: 20

CONCENTRATION UNITS:

( $u g / L$ or $u g / K g$ ) UG/KG

\begin{tabular}{|c|c|c|c|c|}
\hline $\begin{array}{l}\text { CAS NUMBER } \\
=0=0=0=0=0=0 \\
1 . \\
2 . \\
3 . \\
4 . \\
5 . \\
6 . \\
7 . \\
8 . \\
9 . \\
10 . \\
11 . \\
12 . \\
13 . \\
14 . \\
15 . \\
16 . \\
17 . \\
18 . \\
19 . \\
20 .\end{array}$ & $\begin{array}{l}\text { COMPOUND NAME } \\
\text { UNKNOWN OYXGENATED COMPOUND } \\
\text { UNKNOWN } \\
\text { UNKNOWN OYXGENATED COMPOUND } \\
\text { UNKNOWN KETONE } \\
\text { UNKNOWN } \\
\text { UNKNOWN ALKANOIC ACID } \\
\text { UNKNOWN } \\
\text { UNKNOWN } \\
\text { UNKNOWN } \\
\text { UNKNOWN } \\
\text { UNKNOWN OYXGENATED COMPOUND } \\
\text { UNKNOWN ALKANE } \\
\text { UNKNOWN OYXGENATED COMPOUND } \\
\text { UNKNOWN } \\
\text { UNKNOWN SUBSTITUTED ALKANE } \\
\text { UNKNOWN } \\
\text { UNKNOWN } \\
\text { UNKNOWN ALKANE } \\
\text { UNKNOWN } \\
\text { UNKNOWN }\end{array}$ & \begin{tabular}{|c|} 
RT \\
\hdashline 4.72 \\
5.17 \\
5.60 \\
6.78 \\
8.27 \\
22.12 \\
26.92 \\
28.86 \\
31.06 \\
31.09 \\
31.29 \\
31.34 \\
32.61 \\
33.06 \\
33.17 \\
33.51 \\
33.82 \\
35.19 \\
37.82 \\
38.09
\end{tabular} & \begin{tabular}{r|} 
EST. CONC. \\
1100 \\
480 \\
1100 \\
800 \\
750 \\
1800 \\
490 \\
510 \\
620 \\
580 \\
740 \\
560 \\
590 \\
540 \\
3400 \\
1200 \\
3400 \\
2400 \\
900 \\
2600
\end{tabular} & 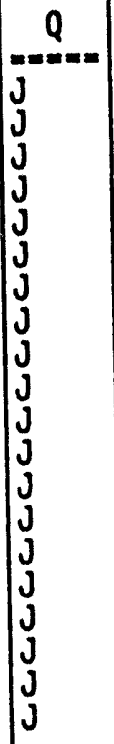 \\
\hline
\end{tabular}

FORM I SV-TIC 
$1 B$

SEMIVOLATILE ORGANICS ANALYSIS DATA SHEET

Lab Name: ENSECO

Lab Code: ECAL

Case No.: 65147

Contract:

SAS No.:

BS -125

SDG No. : BS-124
Matrix: (soll/water) SOIL

Sample wt/vol:

$30.0(\mathrm{~g} / \mathrm{mL}) \mathrm{G}$

Level: (low/mcd) LOW

\% Moisture: 84 decanted: $(Y / N) N$

Concentrated Extract Volume: 500.0 (UL)

Injection Volume:

2.0(UL)

GPC Cleanup: $\quad(Y / N) Y$

CAS NO.
pH: 4.8 COMPOUND

EPA SAMPLE NO.

Lab File ID: 6514721RI

Date Received: 07/28/92

Date Extracted: 07/30/92

Date Analyzed: 08/13/92

Dilution Factor: 1.0
108-95-2.......-Phenol

$111-44-4 \ldots . . .-$ bis (2-Chroroethy) Ether

$95-57-8 \ldots \ldots-2-2-$ - Chiorophenol

541-73-1 ......-1,3-Dichlorobenzene

106-46-7 -......-1,4-Dichlorobenzene

$95-50-1 \ldots \ldots \ldots-1,2-0$ ichlorobenzene

95-48-7-.......-2-Methylphenol

$108-60-1 \ldots \ldots \ldots-2,2^{\prime}-0 x y b i s$ (1 - ch Toropropane

106-44-5-.....-4-Methyiphenol

$621-64-7-\ldots . .-N-N i$ troso-Di-n-Propylamine

$67-72-1 \ldots \ldots . . . .$. Hexachloroethane

98-95-3.......-Nitrobenzene

78-59-1 ......... I sophorone

$88-75-5-\ldots \ldots . .2-2-N i$ tropheno

$105-67-9 \ldots \ldots-2,4-0$ imethylpheno

111-91-1......-bis (2-Chloroethoxy) Methane

120-83-2 ......-2,4-Dichlorophenol

120-82-1 ........-1,2,4-Trichlorobenzene

$91-20-3 \ldots . . . .-$ Naph thatene

106-47-8-.....-4-Chioroan TTine

87-68-3........-Hexachlorobutadiene

59-50-7.......-4-Chioro-3-Methylphenol

91 -57-6-........-2-Methyinaphthaiene

77-47-4 .........-Hexach orocyclopentadiene

88-06-2 .......-2, 4,6-Trichlorophenol

$95-95-4 \ldots \ldots \ldots-2,4,5-$ Trichlorophenol

91-58-7-......-2-Chioronaphthalene

88-74-4-.....-2-2-Nitroanfline

131-11-3-......-Dimethyl Phthatate

208-96-8-.....-Acenaphthylene

606-20-2 ......-2,6-0 initrotoluene

99-09-2 .......-3-Nitroaniline

83-32-9.......-Acenaphthene
CONCENTRATION UNITS:

(ug/L or $u g / K g$ ) UG/KG $Q$
2100

2100

2100

2100

2100

2100

2100

2100

2100

2100

2100

2100

2100

2100

2100

2100

2100

2100

2100

2100

2100

2100

2100

2100

2100

5000

2100

5000

2100

2100

2100

5000

2100 
$1 C$

SEMIVOLATILE ORGANICS ANALYSIS DATA SHEET

Lab Name: ENSECO

Contract:

Case No.: 65147

SAS No.:

Matrix: (soll/water) SOIL

Sample wt/vol: $\quad 30.0(\mathrm{~g} / \mathrm{mL}) \mathrm{G}$

Level: (low/med) LOW

* Moisture: 84 decanted: (Y/N) N

Concentrated Extract Volume: 500.0 (uL)

Injection Volume: $\quad 2.0(\mathrm{uL})$

GPC Cleanup: $\quad(Y / N) Y \quad$ pH: 4.8

CAS NO. COMPOUND
EPA SAMPLE NO.

BS- 125

SDG No.: BS-124

Lab Sample ID: 65147-21

Lab File ID: $6514721 R I$

Date Received: 07/28/92

Date Extracted: 07/30/92

Date Analyzed: 08/13/92

Dilution Factor: 1.0

CONCENTRATION UNITS:

( $u g / L$ or $u g / K g$ ) UG/KG $Q$

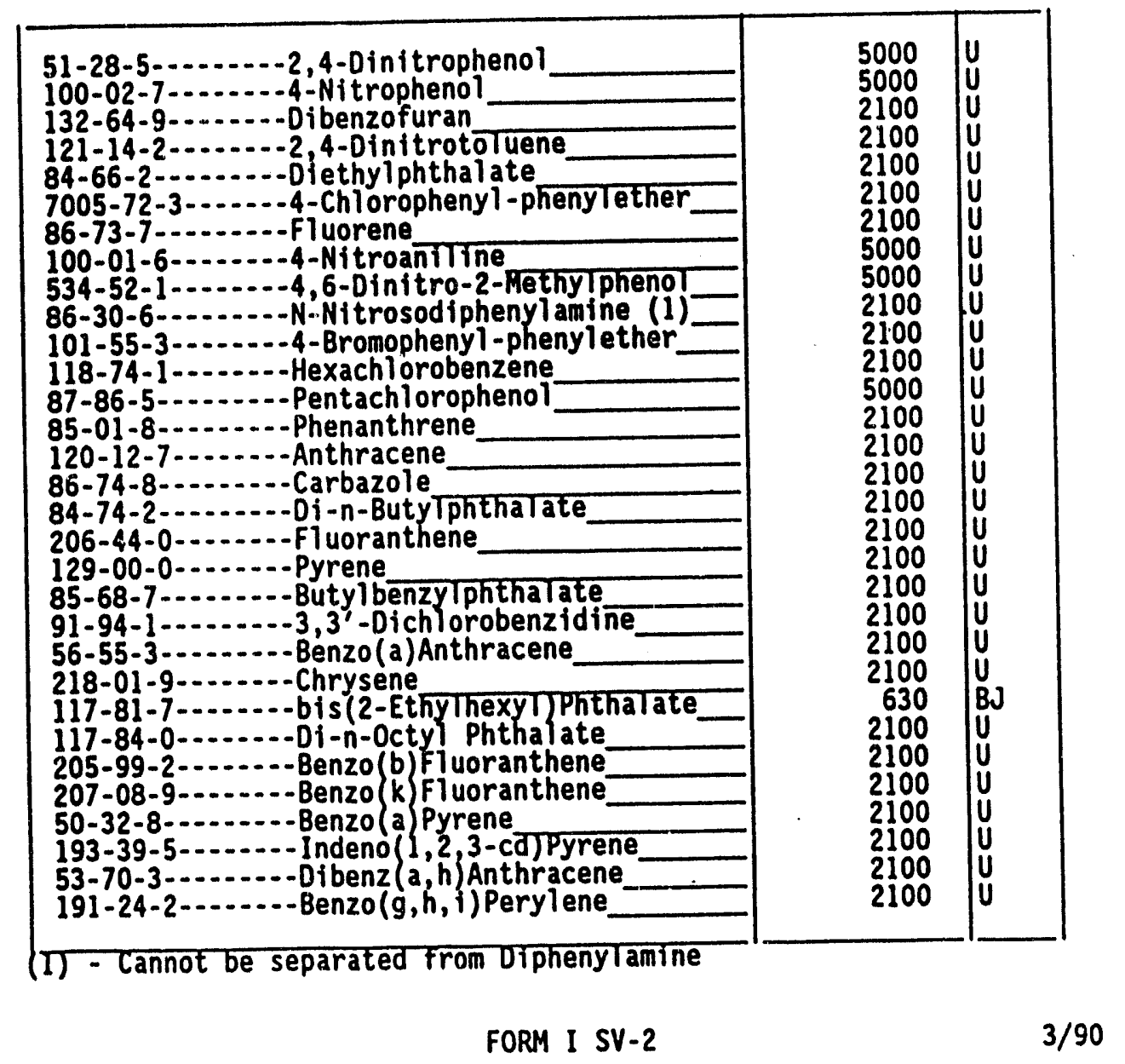


$1 F$

SEMIVOLATILE ORGANICS ANALYSIS DATA SHEET TENTATIVELY IDENTIFIED COMPOUNDS

Lab Name: ENSECO

Contract:

Lab Code: ECAL Case No.: 65147 SAS No.:
EPA SAMPLE NO.

BS- 125

SDG No.: BS-124

Lab Sample ID: 65147-21

Matrix: (soil/water) SOIL

Sample wt/vol: $\quad 30.0(\mathrm{~g} / \mathrm{mL}) \mathrm{G}$

Lab File ID: 6514721RI

Level: (low/med) LOW

Date Received: 07/28/92

\% Moisture: 84 decanted: $(Y / N) N$

Date Extracted: $07 / 30 / 92$

Concentrated Extract Volume: 500.0 (UL)

Date Analyzed: 08/13/92

Injection Volume:

2.0(UL)

Dilution Factor: 10

GPC Cleanup: $\quad(Y / N) Y$

$\mathrm{pH}: \quad 4.8$

CONCENTRATION UNITS:

Number TICs found: 20

(ug/L or $u g / K g$ ) $U G / K G$

\begin{tabular}{|c|c|c|c|c|}
\hline 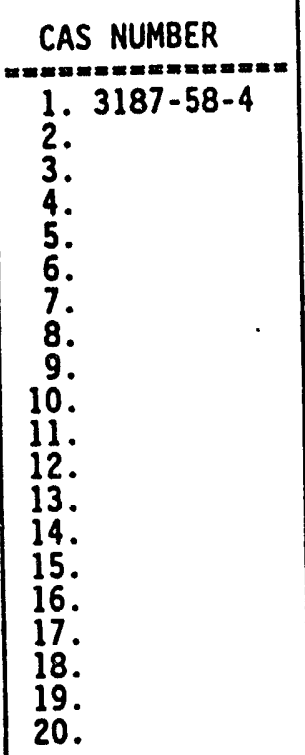 & 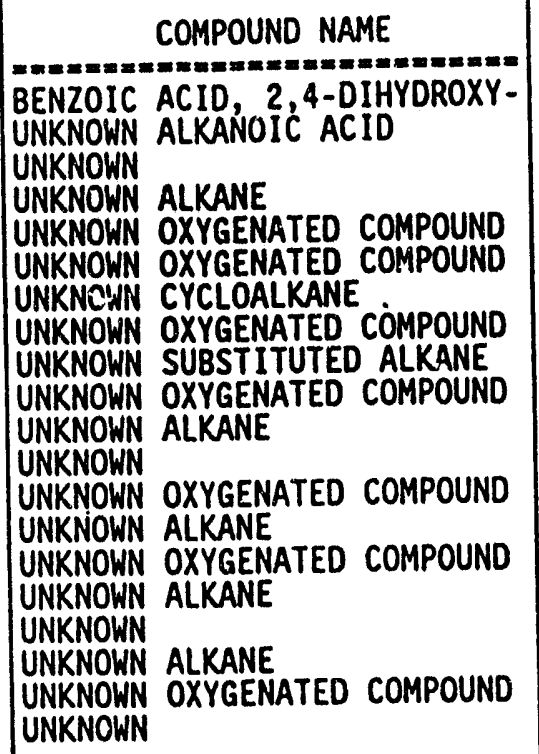 & \begin{tabular}{|c|}
$R T$ \\
$=n=m=m=$ \\
19.19 \\
22.22 \\
25.44 \\
28.76 \\
29.32 \\
30.72 \\
31.37 \\
31.69 \\
32.29 \\
32.66 \\
33.34 \\
33.41 \\
33.56 \\
34.14 \\
34.57 \\
35.41 \\
35.51 \\
36.56 \\
37.22 \\
37.97
\end{tabular} & 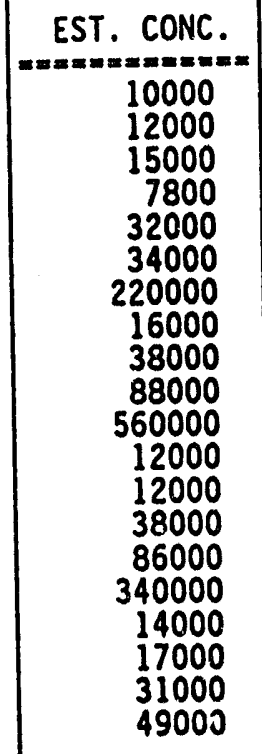 & 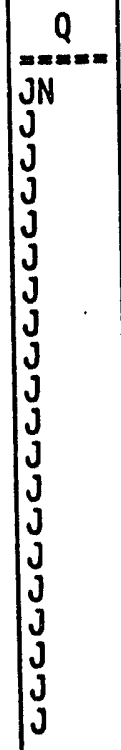 \\
\hline
\end{tabular}

FORM I SV-TIC 
$1 B$

SEMIVOLATILE ORGANICS ANALYSIS DATA SHEET

Lab Name: ENSECO

Case No.: 65147

Lab Code: ECAL

Contract:

SAS No.:

Lab Sample ID: 65147-22

Matrix: (soil/water) SOIL

Sample wt/voi : $\quad 30.0(\mathrm{~g} / \mathrm{mL}) \mathrm{G}$

Level: (1ow/med) LOW

* Moisture: 5 cecanted: $(Y / N) N$

Concentrated Extract Volume: 500.0 (UL)

Injection Volume: $2.0(\mathrm{UL})$

GPC sleanup: $\quad(Y / N) Y . \quad$ PH: 7.7 CONCENTRATION UNITS:

Lab File ID: 6514722RI

Date Received: $07 / 28 / 92$

Date Extracted: $07 / 30 / 92$

Date Analyzed: 08/13/92

Dilution Factor: 1.0
EPA SAMPLE NO.

BSSD-126

SDG No.: BS-124

CAS NO. COMPOUND ( $\mathrm{Gg} / \mathrm{L}$ or $\mathrm{ug} / \mathrm{Kg}$ ) UG/KG

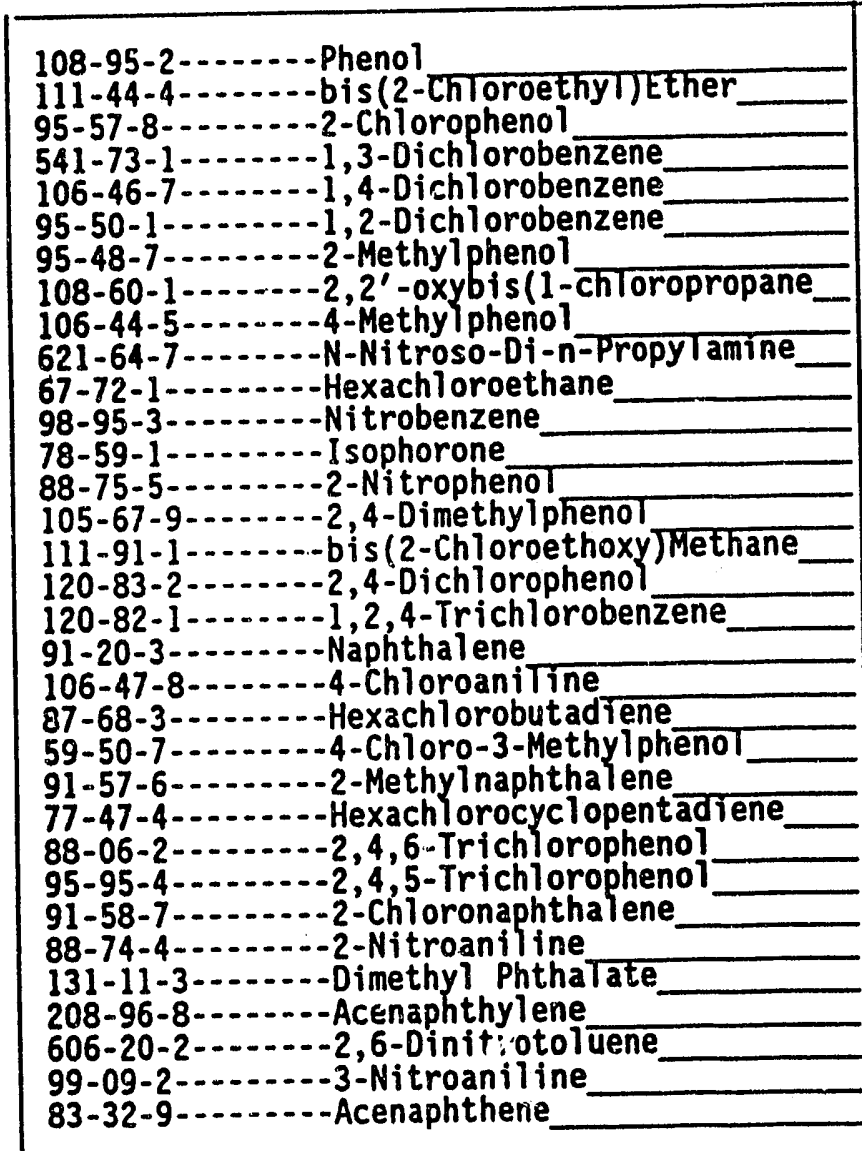

FORM I SV-I 
IC

SEMIVOLATILE ORGANICS ANALYSIS DATA SHEET

EPA SAMPLE NO.

Lab Name: ENSECO

Contract:

BSSD-126

Lab Code: ECAL Case No.: 65147 SAS No.:

SOG No.: BS-124

Matrix: (soil/water) SOIL

Lab Sample ID: 65147-22

Sample wt/vol: $\quad 30.0(\mathrm{~g} / \mathrm{mL}.) \mathrm{G}$

Lab File ID: 6514722RI

Level: (low/med) LOW

* Moisture: 5 decanted: $(Y / N) N$

Date Recęived: 07/28/92

Concentrated Extract Volume: 500.0 (UL)

Date Extracted: 07/30/92

Injection Volume:

$2.0(u L)$

Date Analyzed: 08/13/92

GPC Cleanup: $\quad(Y / N) Y$

pH: 7.7

CAS NO.

COMPOUND

CONTRATION UNITS:

(ug/L or $u g / K g$ ) UG/KG Q

\begin{tabular}{|c|c|c|}
\hline 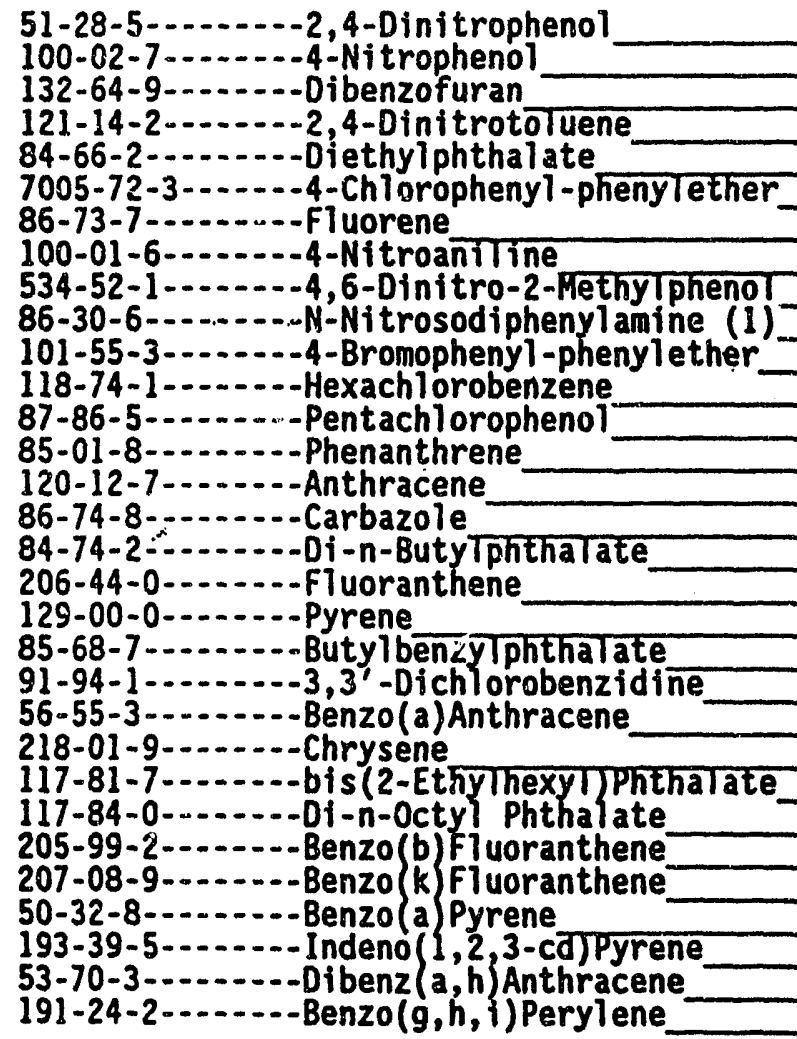 & $\begin{array}{l}840 \\
840 \\
350 \\
350 \\
350 \\
350 \\
350 \\
840 \\
840 \\
350 \\
350 \\
350 \\
840 \\
350 \\
350 \\
350 \\
350 \\
350 \\
350 \\
350 \\
350 \\
350 \\
350 \\
79 \\
350 \\
350 \\
350 \\
350 \\
350 \\
350 \\
350\end{array}$ & $\begin{array}{l}U \\
U \\
U \\
U \\
U \\
U \\
U \\
U \\
U \\
U \\
U \\
U \\
U \\
U \\
U \\
U \\
U \\
U \\
U \\
U \\
U \\
U \\
U \\
B J \\
U \\
U \\
U \\
U \\
U \\
U \\
U \\
U\end{array}$ \\
\hline
\end{tabular}

FORM 1 SV-2

$3 / 90$ 
IF

SEMIVOLATILE ORGANICS ANALYSIS DATA SHEET

TENTATIVELY IDENTIF IED COMPOUNDS

Lab Name: ENSECO

Contract:

Lab Code: ECAL Case No.: 65147 SAS No.:

Matrix: (soil/water) SOIL

Sample wt/vol: $\quad 30.0(\mathrm{~g} / \mathrm{mL}) \mathrm{G}$

Level: (low/med) LOW .

* Moisture: $\quad 5$ decanted: $(Y / N) N$

Concentrated Extract Volume: 500.0 (UL)

Injection Volume: $\quad 2.0(\mathrm{UL})$

GPC Cleanup: $\quad(Y / N) Y \quad$ PH: 7.7

Number TICS found: 20
EPA SAMPLE NO.

BSSD-126

SDG No.: BS-124

Lab Sample ID: 65147-22

Lab File 1D: 6514722RI

Date Received: 07/28/92

Date Extracted: 07/30/92

Date Analyzed: 08/13/92

Dilution Factor: 1.0

\begin{tabular}{|c|c|c|c|c|}
\hline $\begin{array}{l}\text { CAS NUMBER } \\
==x==x==x===x== \\
1 . \\
2 . \\
3 . \\
4 . \\
5 . \\
6 . \\
7.10544-50-0 \\
8 . \\
9 . \\
10 . \\
11 . \\
12 . \\
13 . \\
14 . \\
15 . \\
16 . \\
17 . \\
18 . \\
19 . \\
20 .\end{array}$ & 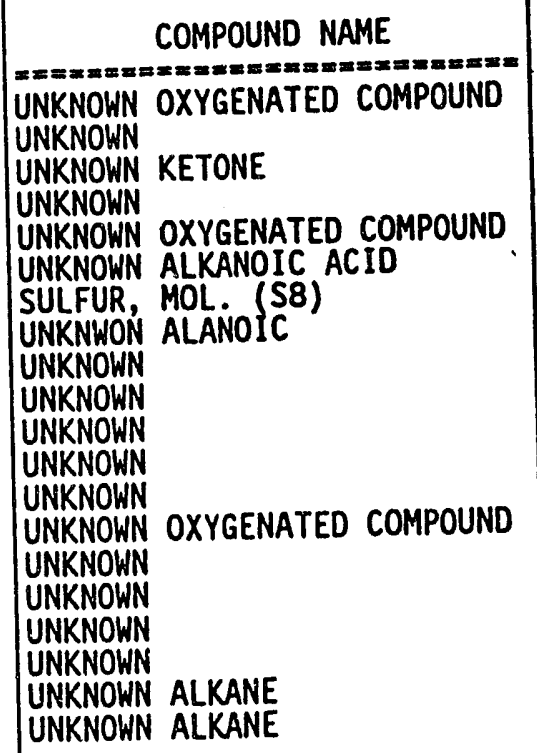 & \begin{tabular}{|c|}
$R T$ \\
$==x==x=1$ \\
4.72 \\
5.17 \\
5.58 \\
6.78 \\
8.28 \\
22.09 \\
24.25 \\
28.19 \\
29.29 \\
30.29 \\
30.37 \\
31.22 \\
31.87 \\
33.17 \\
33.59 \\
33.99 \\
34.47 \\
35.14 \\
36.47 \\
38.06
\end{tabular} & $\begin{array}{r}\text { EST. CONC. } \\
===x=x==x===x \\
860 \\
790 \\
420 \\
550 \\
630 \\
700 \\
2200 \\
260 \\
150 \\
730 \\
430 \\
2800 \\
1800 \\
330 \\
7600 \\
13000 \\
480 \\
1000 \\
250 \\
230\end{array}$ & 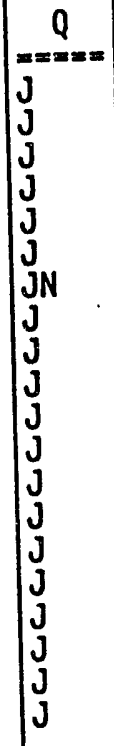 \\
\hline
\end{tabular}

FORM I SV-TIC

$3 / 90$ 
$1 B$

SEMIVOLATILE ORGANICS ANALYSIS DATA SHEET

Lab Name: ENSECO

Lab Code: ECAL Case No.: 65147

Matrix: (soil/water) SOIL

Sample wt/vol:

$30.0(\mathrm{~g} / \mathrm{mL}) \mathrm{G}$

Level: (low/med) LOW

\% Moisture: 12 decanted: $(Y / N) N$

Concentrated Extract Volume: 500.0 (uL)

Injection Volume: $\quad 2.0(u L)$

GPC Cleanup: $\quad(Y / N) Y$

Contract:

SAS No.:

Lab Sample ID: 65147-23

Lab File ID: 6514723RI

Date Received: 07/28/92

Date Extracted: 07/30/92

Date Analyzed: 08/13/92

Dilution Factor: 1.0

$\mathrm{pH}: \quad 7.4$

CONCENTRATION UNITS:

CAS NO.

(ug/L or $u g / K g$ ) UG/KG Q

108-95-2-.....-Phenol

$111-44-4-\ldots \ldots$ - bis (2-ChToroethyt) Ether

95-57-8-....-.-2-Chlorophenol

541-73-1 ....... 1, 3-Dich Torobenzene

106-46-7-......1, 4-Dichlorobenzene

$95-50-1 \ldots \ldots \ldots-1,2-D i c h i o r o b e n z e n e$

$95-48-7 \ldots \ldots . . .-2-$ Methylphenol

108-60-1 $\ldots \ldots \ldots-2,2^{\prime}$-oxybis (1-chtoropropane

$106-44-5-\ldots \ldots$ - 4-Methyl phenol

$621-64-7 \ldots \ldots-N-N i$ troso-Di -n-Propylamine.

$67-72-1 \ldots \ldots . . . . .-$ Hexachloroethane

98-95-3-.......-Nitrobenzene

78-59-1 -.....--Isophorone

88-75-5-...-2-2-Nitropheño

105-67-9......-2, 4-Dimethylphenol

111-91-1 -.....-bis (2-Ch) oroethoxy) Methane

120-83-2 ......-2, 4-Dichlorophenol

$120-82-1 \ldots \ldots-1,2,4-$ Trichlorobenzene

$91-20-3-\ldots \ldots$-... Naphthalene

106-47-8-...--4-Chloroanitine

87-68-3-.......- Hexachlorobutadiene

59-50-7-.....-.-4-Chioro-3-Methylphenol

$91-57-6 \ldots \ldots \ldots-2-$ - Methyinaphthalene

77-47-4-.....-.-Hexachlorocyclopent adiene

88-06-2 .......-2,4,6-Trichiorophenol

$95-95-4 \ldots \ldots \ldots-2,4,5-$ Trichlorophenol

$91-58-7-\ldots . .-2-C h$ - 1 oronaphthalene

$88-74-4-\ldots \ldots-2-N i t r o a n i l$ - 2 -Ne

$131-11-3-\ldots . .-$ Dimethy 1 Phthatate

208-96-8-.....-Acenaphthylene

606-20-2 ......-2,6-Dinitrotoluene

99-09-2-......-3-Nitroaniline

83-32-9-.....-Acenaphthene 
IC

SEMIVOLATILE ORGANICS ANALYSIS DATA SHEET

Lab Name: ENSECO

Case No.: 65147

\section{Contract:}

SAS No.:
Lab Code: ECAL
EPA SAMPLE NO.

BSSD-127

SDG No.: BS-124

\section{SOIL}

Sample wt/vol:

$30.0(\mathrm{~g} / \mathrm{mL}) \mathrm{G}$

Level: (low/med) LOW

\% Moisture: 12 decanted: $(Y / N) N$

Concentrated Extract Volume: 500.0 (UL)

Injection Volume:

2.0(UL)
Lab Sample ID: 65147-23

Lab File ID: 6514723RI

Date Received: 07/28/92

Date Extracted: 07/30/92

Date Analyzed: 08/13/92

Dilution Factor: 1.0

GPC Cleanup: (Y/N) Y PH: 7.4 CONCENTRATION UNITS:

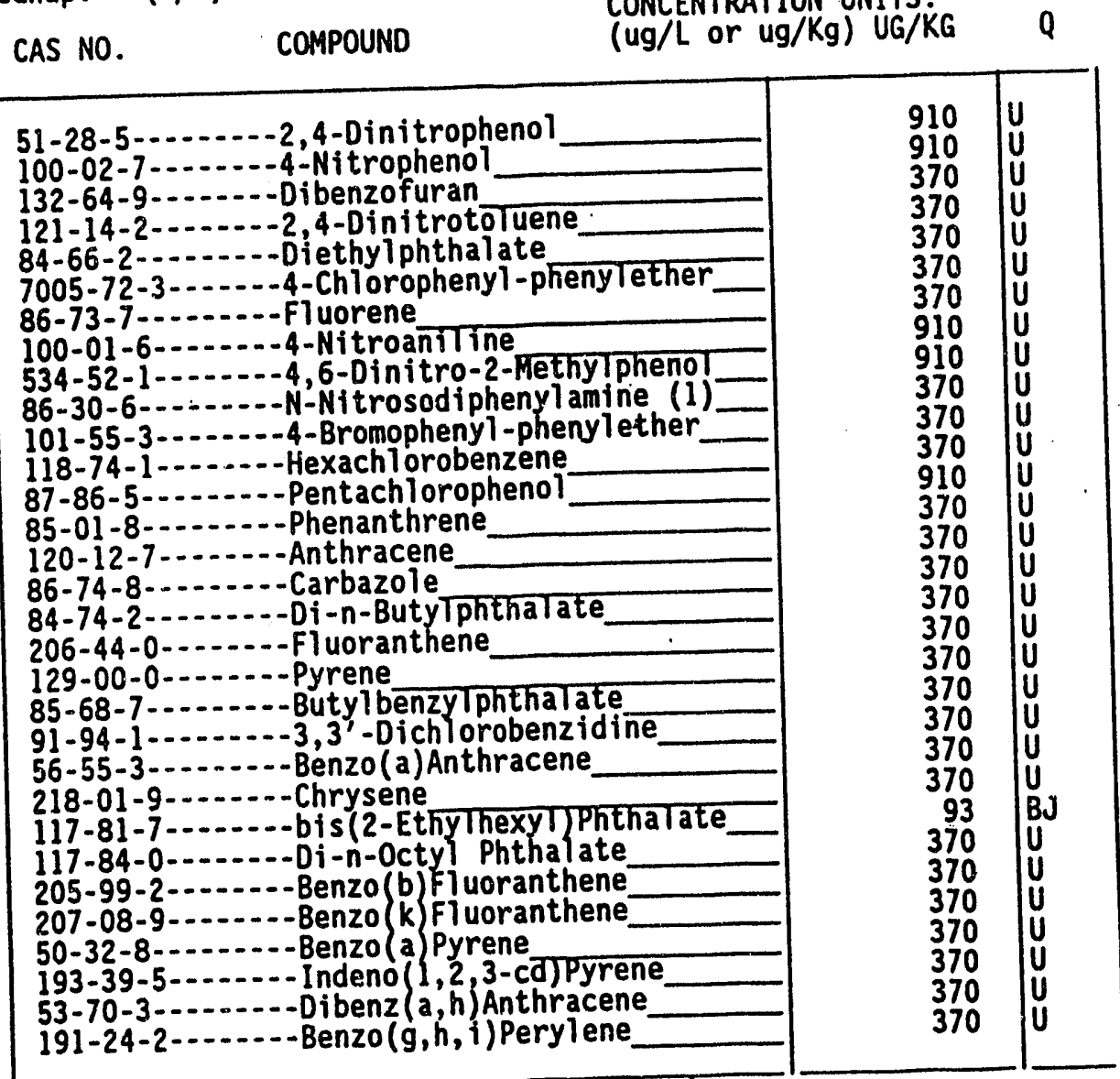

(I)- Cannot be separated from Diphenylamine

FORM I SV-2 
SEMIVOLATILE ORGANIC'S ANALYSIS DATA SHEET TENTATIVELY IDENTIF IED COMPOUNDS

Lab Name: ENSECO

Case No.: 65147

Contract:

Lab Code: ECAL

SAS No.:

Matrix: (soil/water) SOIL

Sample wt/vol:

$30.0(\mathrm{~g} / \mathrm{mL}) \mathrm{G}$

Level: (low/med) LOW

\% Moisture: 12 decanted: $(Y / N) N$

Concentrated Extract Volume: 500.0

(uL)

Injection Volume:

$2.0(u L)$

GPC Cleanup: $\quad(Y / N) Y$

$\mathrm{pH}: \quad 7.4$
BSSD- 127

SDG No.: BS-124

Number TICs found: 20

CONCENTRATION UNITS:

(ug/L or $u g / K g$ ) UG/KG

\begin{tabular}{|c|c|c|c|c|}
\hline $\begin{array}{l}\text { CAS NUMBER } \\
==m==m== \pm== \pm== \\
1 . \\
2 . \\
3 . \\
4 . \\
5 . \\
6 . \\
7 . \\
8 . \\
9 . \\
10544-50-0 . \\
11 . \\
12 . \\
13 . \\
14 . \\
15 . \\
16 . \\
17 . \\
18 . \\
19 . \\
20 .\end{array}$ & 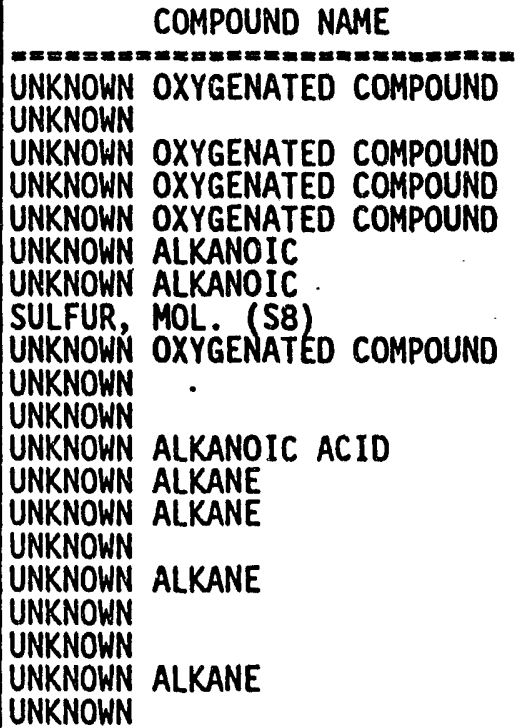 & 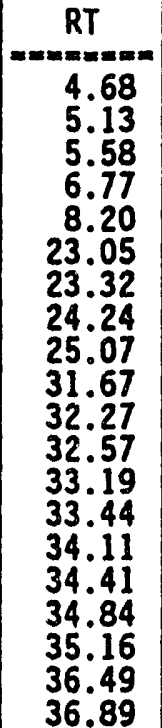 & \begin{tabular}{|c|} 
EST. CONC. \\
610 \\
340 \\
810 \\
870 \\
620 \\
540 \\
300 \\
930 \\
350 \\
290 \\
240 \\
370 \\
320 \\
420 \\
260 \\
370 \\
290 \\
1200 \\
280 \\
260
\end{tabular} & 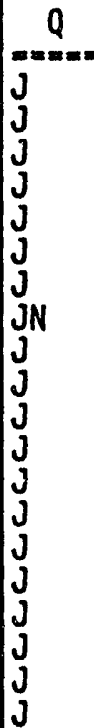 \\
\hline
\end{tabular}

FORM I SV-TIC 
$1 \mathrm{~A}$

VOLATILE ORGANICS ANALYSIS DATA SHEET

Lab Name: ENSECO

Lab Code: ECAL Case No.: 65147

Yatrix: (soil/water) SOIL

Sample wt/vol: $\quad 5.0(\mathrm{~g} / \mathrm{mL}) \mathrm{G}$

Level: (low/med) LOW

\% Moisture: not dec. $\cdot 23$

GC Column: CAP ID: $0.530(\mathrm{~mm})$

Soil Extract Volume: (uL)
Contract:

SAS No.:
EPA SAMPLE NO.

BS -124

SDG No.: BS-124

Lab Sample ID: $65147-20$

Lab File ID: $\quad$ S1895

Date Received: 07/28/92

Date Analyzed: 08/06/92

Dilution Factor: 1.0

Soil Aliquot Volume:

(uL)

CONCENTRATION UNITS:

(ug/L or $u g / K g$ ) UG/KG Q

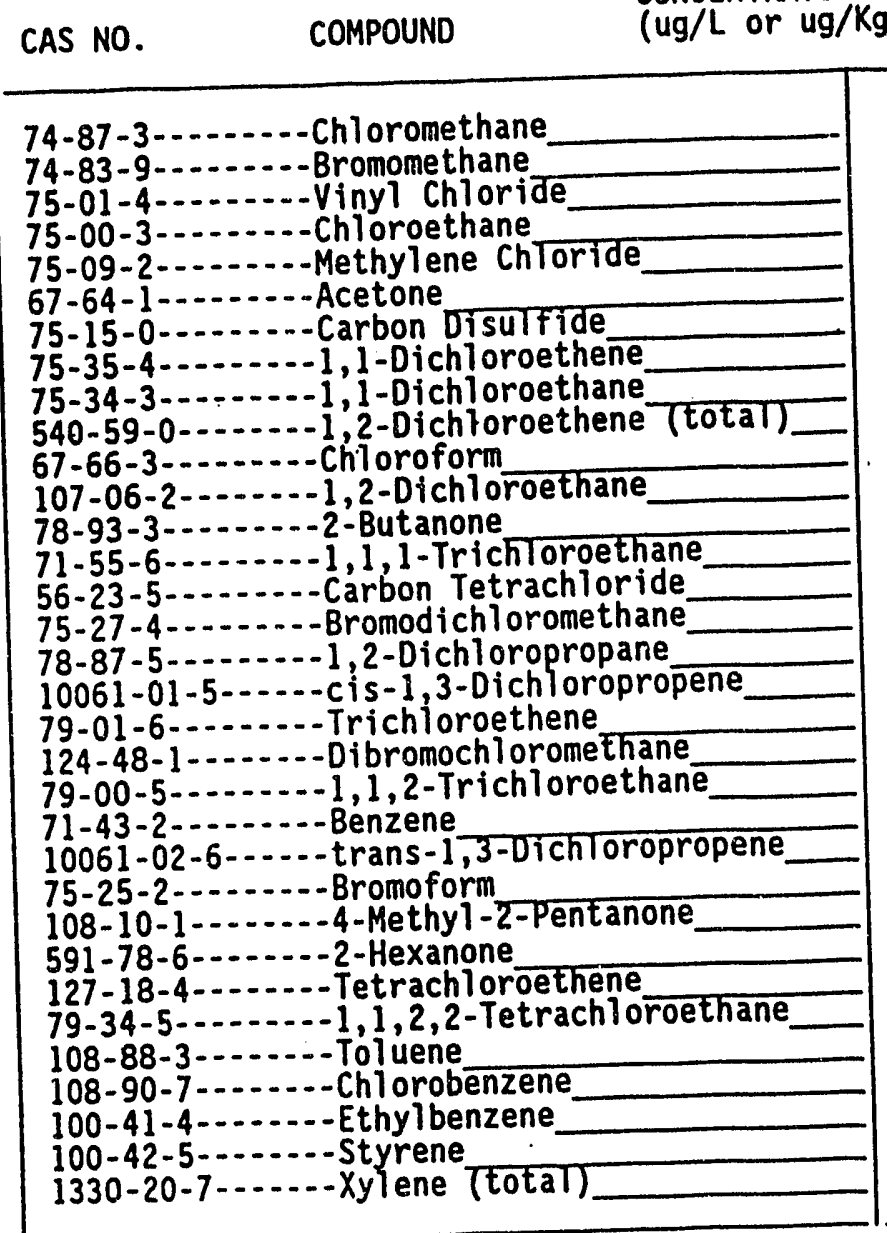

FORM I VOA 
$1 E$

VOLATILE ORGANICS ANALYSIS DATA SHEET TENTATIVELY IDENTIFIED COMPOUNDS

Lab Name: ENSECO

Lab Code: ECAL

Case No.: 65147

Matrix: (soil/water) SOIL

Sample wt/vol:

$5.0(\mathrm{~g} / \mathrm{mL}) \mathrm{G}$

Level: (low/med) LOW

\% Moisture: not dec. 23

GC Column: CAP

ID: $0.530(\mathrm{~mm})$

Soil Extract Volume:

(uL)
Contract:

SAS No.:
EPA SAMPLE NO.

BS-124

SDG No.: BS-124

Lab Sample 1D: $65147-20$

Lab File ID: $\quad$ S1895

Date Received: 07/28/92

Date Analyzed: 08/06/92

Dilution Factor: 1.0

Soil Aliquot Volurne:

(uL)

Number TICs found: 0

CONCENTRATION UNITS:

(ug/L or $u g / K g$ ) UG/KG

\begin{tabular}{|c|c|c|c|c|}
\hline CAS NUMBER & COMPOLND NAME & RT & EST. CONC. & Q \\
& & & COMPONNm \\
\hline
\end{tabular}


$1 A$

VOLATILE ORGANICS ANALYSIS DATA SHEET

Lab Name: ENSECO

Contract:

Lab Code: ECAL

Case No.: 65147

Matrix: (soil/water) SOIL

Sample wt/vol:

$$
5.0(\mathrm{~g} / \mathrm{mL}) \mathrm{G}
$$

Level: (low/med) LOW

* Moisture: not dec. 23

GC Column: CAP ID: $0.530(\mathrm{~mm})$

Soil Extract Volume:

(uL)

SAS No.:
EPA SAMYLE NU.

BS- 125

SDG No.: BS-124

Lab Sample ID: 65147-21

Lab File ID: $\quad$ S1899

Date Received: 07/28/92

Date Analyzed: 08/06/92

Dilution Factor: 1.0

Soil Aliquot Volume:

(uL)

CONCENTRATION UNITS:

CAS NO.

COMPOUND

(ug/L or $u g / K g$ ) UG/KG

Q

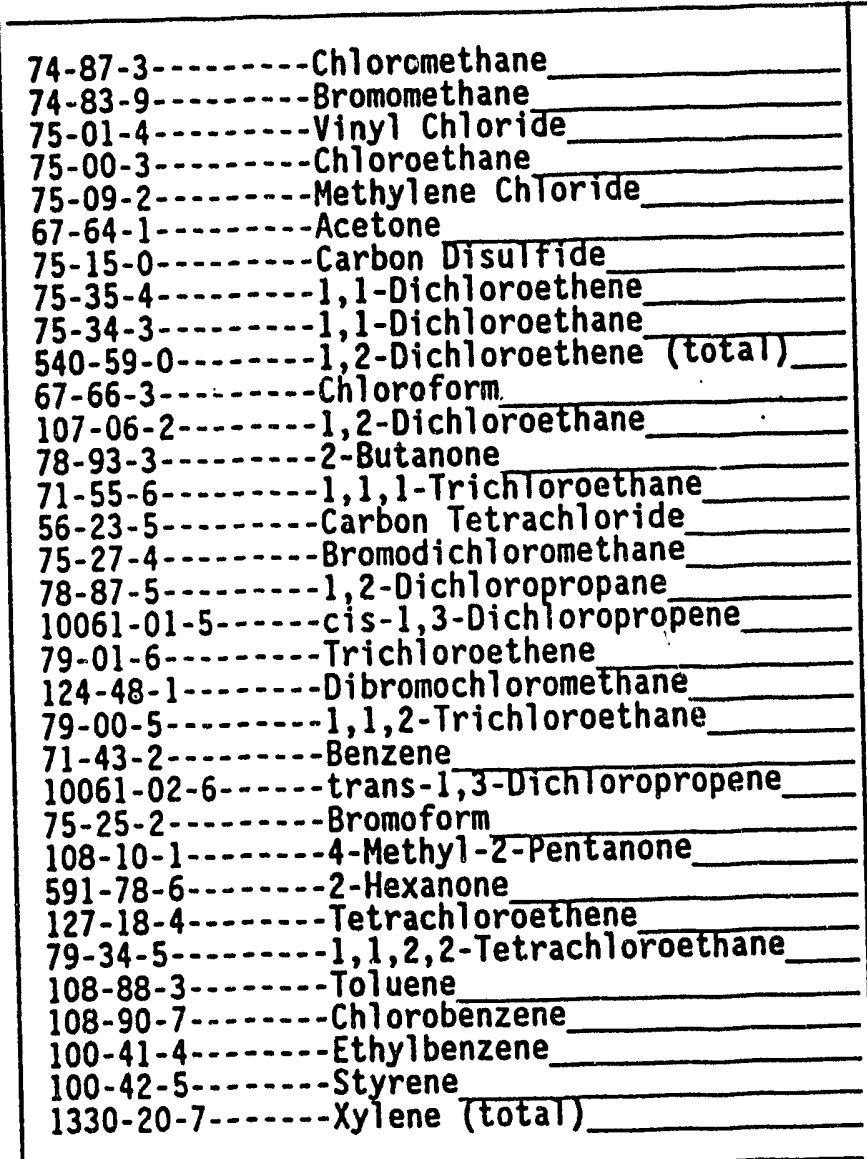

FORM I VOA 
$1 \mathrm{E}$

VOLATILE ORGANICS ANALYSIS DATA SHEET

TENTATIVELY IDENTIFIED COMPOUNDS

Lab Name: ENSECO

Contract:

Lab Code: ECAL

Case No.: 65147

SAS No.:

Lab Sample 1D: 65147-21

Matrix: (soil/water) SOIL

Sample wt/vol:

$5.0(\mathrm{~g} / \mathrm{mL}) \mathrm{G}$

Level: (low/med) LOW

23

* Moisture: not dec.

1D: $0.530(\mathrm{~mm})$

GC Column: CAP

(uL)

Soil Extract Volume:

Number TICs found: 0

Lab File ID: $\quad$ S1899

Date Received: 07/28/92

Date Analyzed: 08/06/92

Dilution Factor: 1.0

Soil Aliquot Volume:

CONCENTRATION UNITS

(ug/L or $u g / K g$ ) UG/KG
THA SAMYLE INU.

BS - 125

SDG No.: BS-124

\begin{tabular}{|c|c|c|c|c|}
\hline CAS NUMBER & COMPOUND NAME & RT & EST. CONC. & $Q$ \\
\hline
\end{tabular}


$1 A$

VOLATILE ORGANICS ANALYSIS DATA SHEET

Lab Name: ENSECO

Lab Code: ECAL Case No.: 65147 SAS No.:

Matrix: (soil/water) SOIL

Sample wt/vol:

$5.0(\mathrm{~g} / \mathrm{mL}) \mathrm{G}$

Level: (low/med) LOW

* Moisture: not dec. 5

GC Column: CAP

ID: $0.530(\mathrm{~mm})$

(uL)
EPA SAMPLE NO.

BSSD-126

SDG No.: BS-124

Lab Sample ID: 65147-22

Lab File ID: $\quad$ S1897

Date Received: 07/28/92

Date Analyzed: 08/06/92

Dilution Factor: 1.0

Soil Aliquot Volume:

(uL)

CONCENTRATION UNITS:
(ug/L or $\mathrm{Ug} / \mathrm{Kg}$ ) UG/KG

a 
$1 E$

VOLATILE ORGANICS ANALYSIS DATA SHEET

TENTATIVELY IDENTIFIED COMPOUNDS

Lab Name: ENSECO

Lab Code: ECAL

Case No.: 65147

Matrix: (soil/water) SOIL

Sample wt/vol:

$5.0(\mathrm{~g} / \mathrm{mL}) \mathrm{G}$

Level: (low/med) LOW

* Moisture: not dec. 5

GC solumn: CAP

ID: $0.530(\mathrm{~mm})$

Soil Extract Volume:

(uL)

Contract:

SAS No.:

Lab Sample 10: 65147-22

Lab File 10: $\quad 51897$

Date Received: 07/28/92

Date Analyzed: 08/06/92

Dilution Factor: 1.0

Soll Aliquot Volume:

(uL)

CONCENTRATION UNITS:

(ug/L or $u g / \mathrm{kg}$ ) UG/KG

Number TICs found: 0

\begin{tabular}{|c|c|c|}
\hline$R T$ & EST. CONC. & $Q$ \\
\hline
\end{tabular}


VOLATILE ORGANICS ÄNALYSIS DATA SHEET

Lab Name: ENSECO

Contract:

BSSD - 127

Lab Code: ECAL Case No.: 65147 SAS No.:

SDG No.: BS-124

Matrix: (soil/water) SOIL

Sample wt/vol:

$5.0(\mathrm{~g} / \mathrm{mL}) \mathrm{G}$

Leve1: (low/med) LOW

* Moisture: not dec. 12

GC Column: CAP $\quad$ ID: $0.530(\mathrm{~mm})$

Soil Extract Volume: (uL)

Lab File 10: $\quad$ S1881

Date Received: 07/28/92

Date Analyzed: 08/04/92

Dilution Factor: 1.0

Soll Aliquot Volume:

(uL)

CONCENTRATION UNITS:

CAS NO. COMPOUND (ug/L or $u g / K g) ~ U G / K G \quad Q$

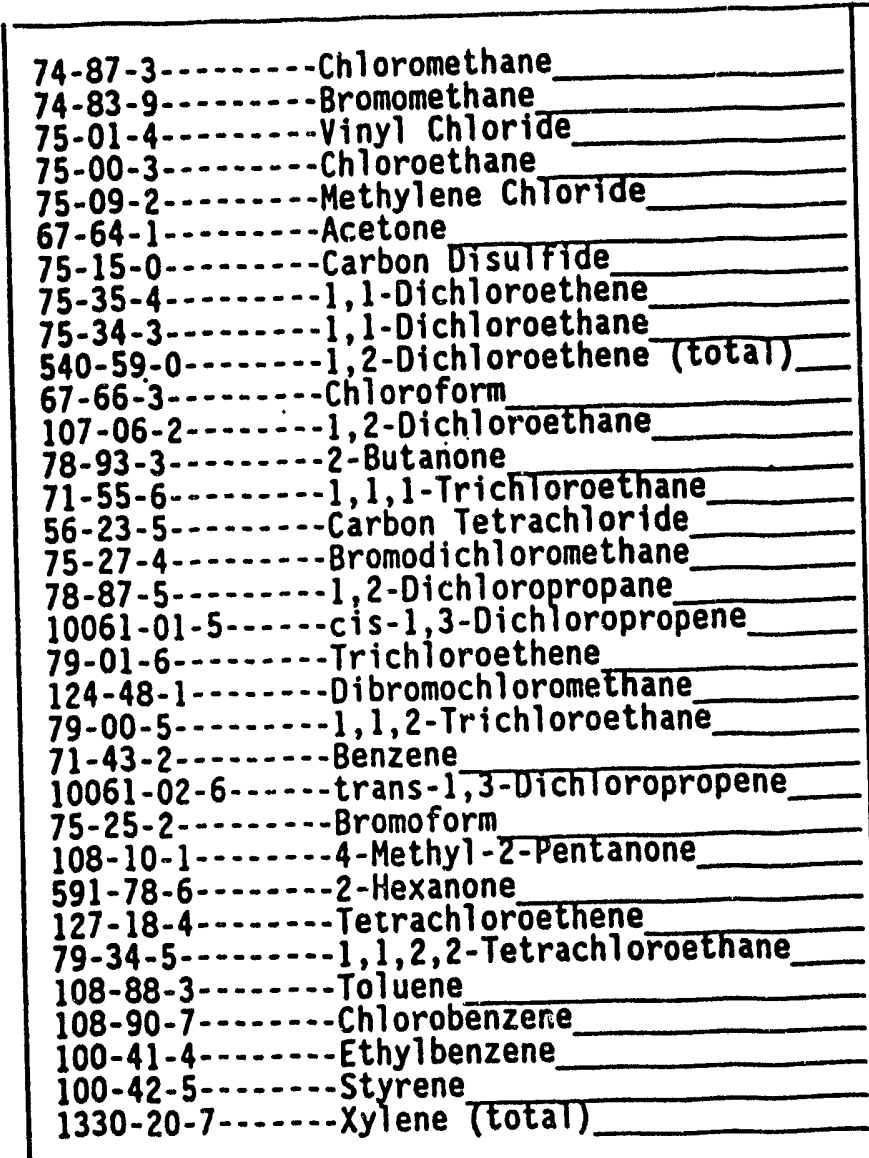

FORM I VOA 


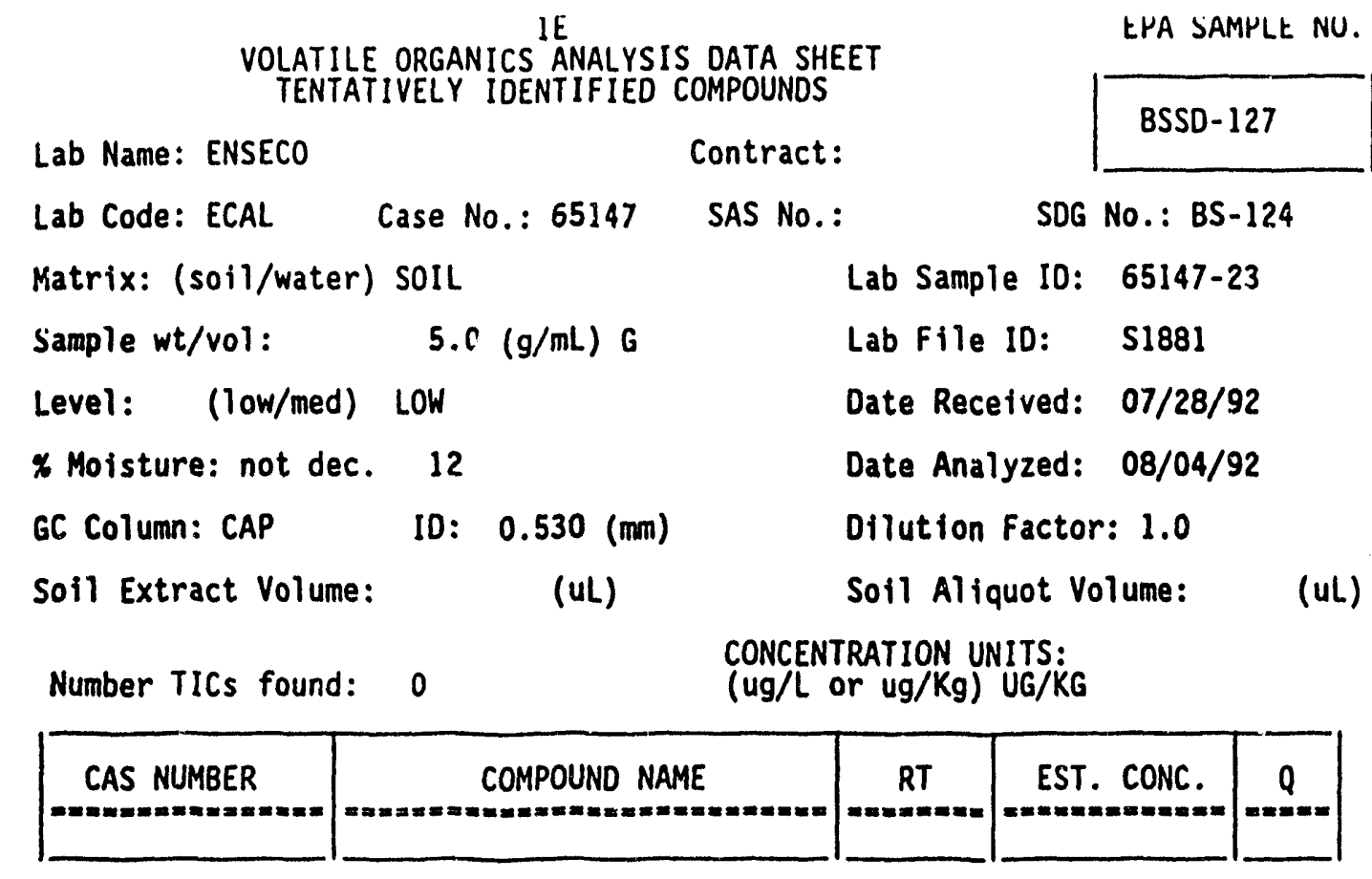


ID

PESTICIDE ORGANICS ANALYSIS DATA SHEET

Lab Name: ENSECO-CAL

Contract: 68-D0-0162

EPA SAMPLE NO.

Iab Code: ECAL Case No.: 65147

SAS No.:

BS124

Matrix: (soil/water) sorL

Sample wt/vol: $\quad 30.0(\mathrm{~g} / \mathrm{mI}) \mathrm{G}$

\& Moisture: 23 decanted: ( $Y / N) N$

Extraction: (SepF/Cont/Sonc) soNC

Concentrated Extract Volume: 5000 (UL)

Iab Sample ID: 65147-20

Injection volume: 1.00 (UL)

GPC Cleanup: $(Y / N) Y \quad$ pH: 6.0

Iab File ID: NA

Date Received: 07/30/92

Date Extracted: 07/30/92

Date Analyzed: 08/26/92

Dilution Factor: 1.00

sulfur cleanup: $(Y / N) Y$

CONCENTRATION UNITS:

(ug/I or ug/Kg) UG/KG Q

CAS NO. COMPOUND (ug/L or ug/Kg) UG/KG

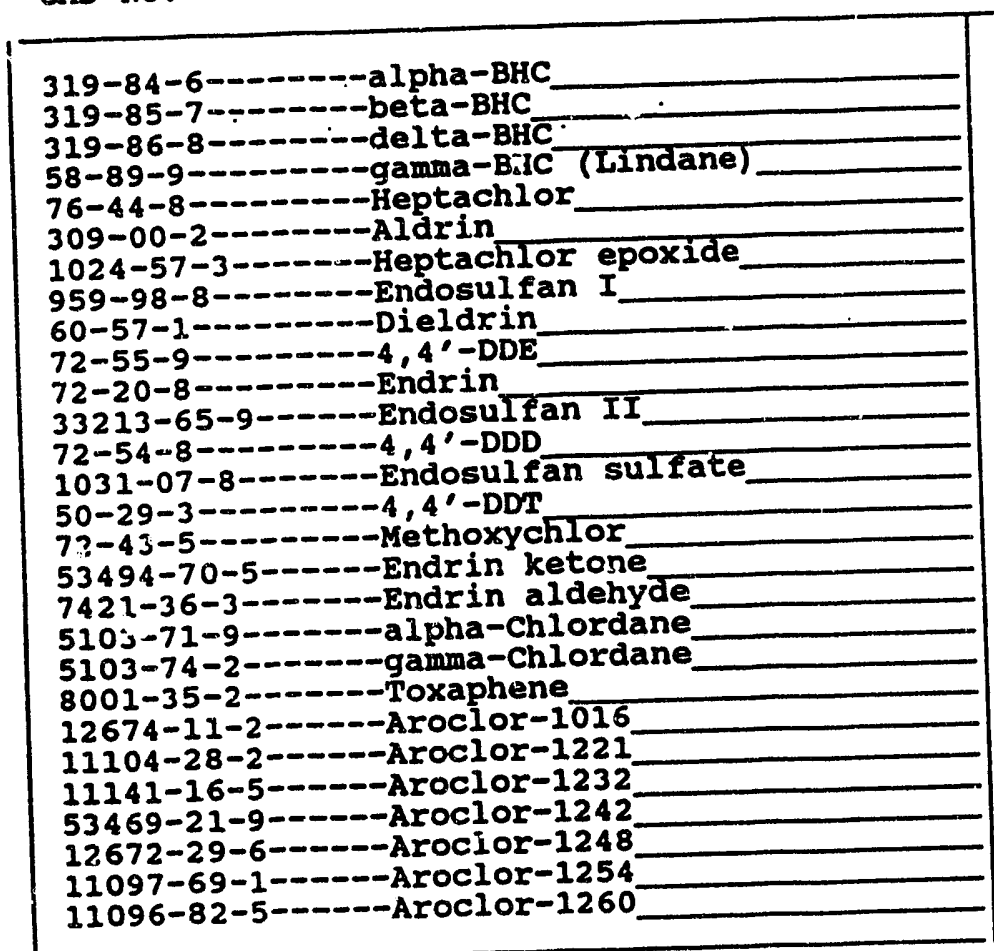

\begin{tabular}{|c|l|}
2.2 & $U$ \\
2.2 & $U$ \\
2.2 & $U$ \\
2.2 & $U$ \\
2.2 & $U$ \\
2.2 & $U$ \\
2.2 & $U$ \\
2.2 & $U$ \\
4.3 & $U$ \\
4.3 & $U$ \\
4.3 & $U$ \\
4.3 & $U$ \\
4.3 & $U$ \\
4.3 & $U$ \\
4.3 & $U$ \\
22 & $U$ \\
4.3 & $U$ \\
4.3 & $U$ \\
2.2 & $U$ \\
2.2 & $U$ \\
220 & $U$ \\
43 & $U$ \\
87 & $U$ \\
43 & $U$ \\
43 & $U$ \\
43 & $U$ \\
43 & $U$ \\
43 & $U$ \\
\hline
\end{tabular}

FORM I PEST 
1D

PESTICIDE ORGANICS ANALYSIS DATA SHEET

EPA SAMPLE NO.

Iab Name: ENSECO-CAL

Iab Code: ECAI Case No.: 65147

Matrix: (soil/water) soIL

Sample wt/vol:

30.0

$(g / m L) G$

\%oisture: 84

decanted: $(Y / N) N$

Extraction: (SepF/Cont/Sonc) SONC

Concentrated Extract Volume:

5000

Injection Volume:

1.00

(uL)

GPC Cleanup: $\quad(Y / N) Y$

CAS NO.

COMPOUND
Contract: 68-D0-0162

SAS NO.:

SDG NO.: BS-124

Lab Sample ID: 65147-2I

Lab File ID: NA

Date Received: $07 / 30 / 92$

Date Extracted: 07/30/92

(UL)

Date Analyzed: $08 / 26 / 92$

Dilution Factor: 1.00

Sulfur Cleanup: $(Y / N) Y$

CONCENTRATION UNITS:

(ug/I or ug/Kg) UG/KG

Q

\begin{tabular}{|c|c|c|}
\hline 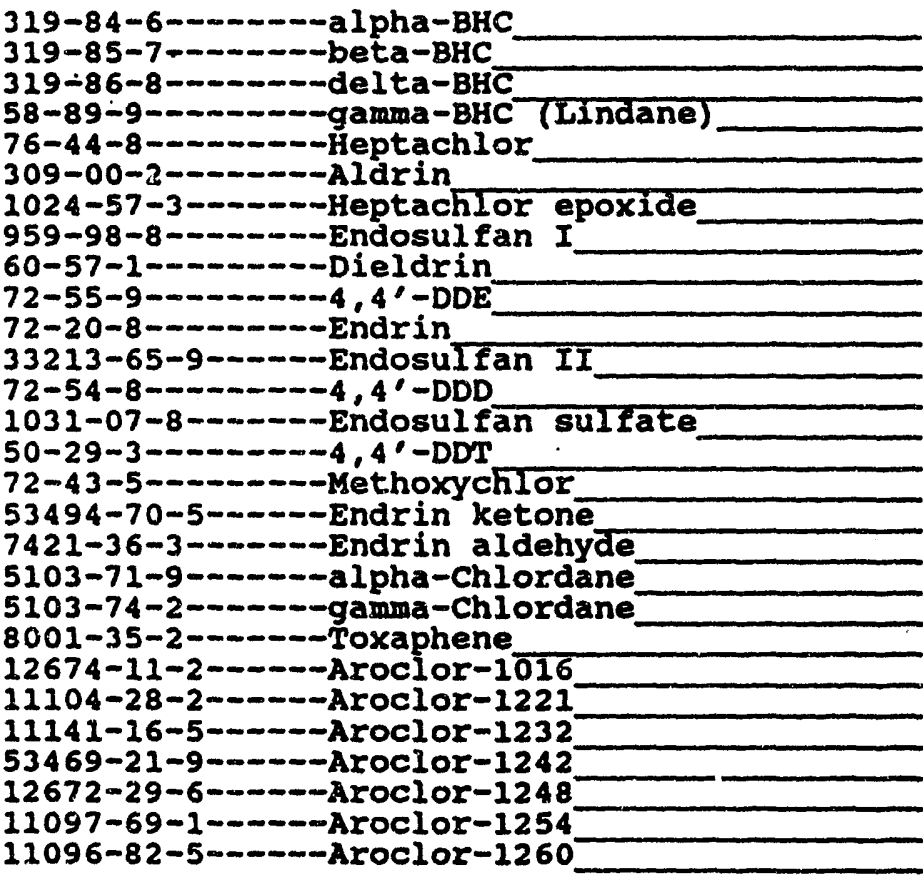 & $\begin{array}{r}11 \\
11 \\
11 \\
11 \\
11 \\
11 \\
11 \\
11 \\
21 \\
21 \\
21 \\
21 \\
21 \\
21 \\
21 \\
110 \\
21 \\
21 \\
11 \\
11 \\
1100 \\
210 \\
420 \\
210 \\
210 \\
210 \\
210 \\
210\end{array}$ & $\begin{array}{l}U \\
U \\
U \\
U \\
U \\
U \\
U \\
U \\
U \\
U \\
U \\
U \\
U \\
U \\
U \\
U \\
U \\
U \\
U \\
U \\
U \\
U \\
U \\
U \\
U \\
U \\
U \\
U\end{array}$ \\
\hline
\end{tabular}


30

PESTICIDE ORGANICS ANALYSIS DATA SHEET

EPA SAMPIE NO.

\section{BSSD126}

Contract: $68-D 0-0162$

SAS NO.:

SDG NO.: BS-124

Iab Code: ECAL Case No.: 65147

Matrix: (soil/water) soIL

Sample wt/vol: $\quad 30.0(\mathrm{~g} / \mathrm{mL}) \mathrm{G}$

Lab Sample ID: 65147-22

t Moisture: 5 decanted: $(X / N)$ N

Lab File ID: NA

Extraction: (SepF/Cont/Sonc) SONC

Concentrated Extract Volume: $\quad 5000$

(uL)

Date Received: $07 / 30 / 92$

Date Extracted: 07/30/92

Injection Volume: 1.00 (uL)

Date Analyzed: 08/26/92

Dilution Factor: 1.00

GPC Cleanup: $\quad(Y / N) Y \quad \mathrm{pH}: 7.7$

Sulfur cleanup: $(Y / N) \quad Y$

CONCENTRATION UNITS:

CAS NO. COMPOUND (ug/L or ug/Kg) UG/KG

\begin{tabular}{|c|c|c|}
\hline 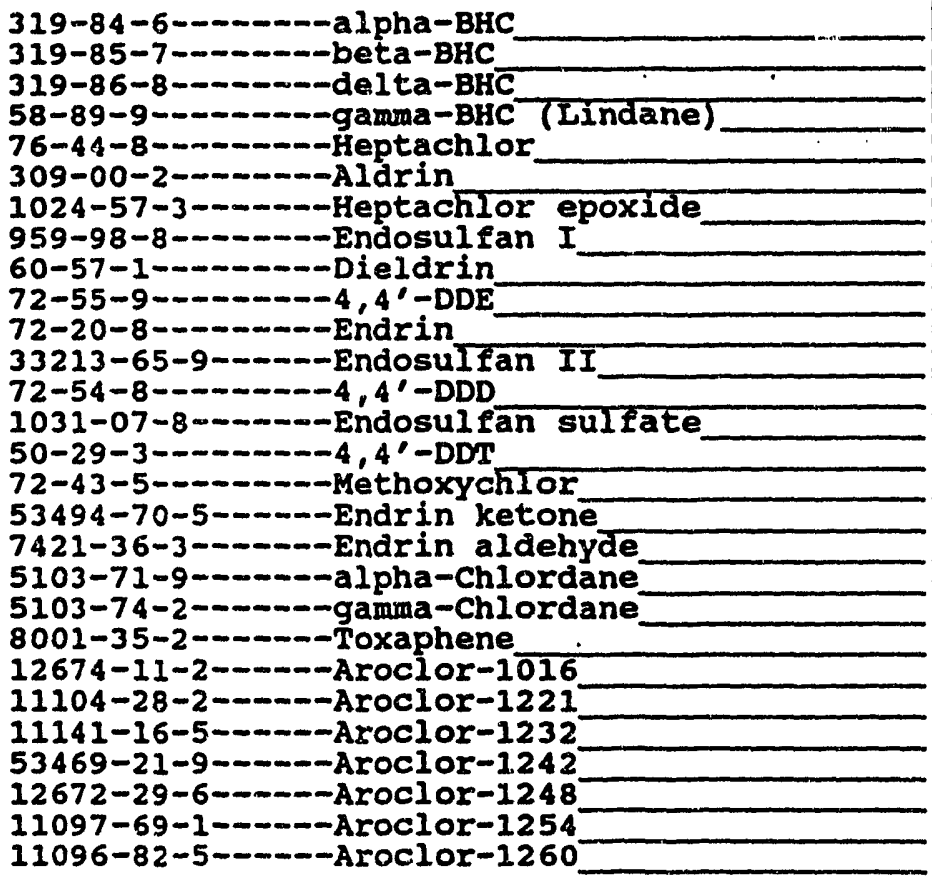 & $\begin{array}{l}1 \cdot 8 \\
1 \cdot 8 \\
1 \cdot 8 \\
1 \cdot 8 \\
1 \cdot 8 \\
1 \cdot 8 \\
1 \cdot 8 \\
1 \cdot 8 \\
3 \cdot 5 \\
3 \cdot 5 \\
3 \cdot 5 \\
3 \cdot 5 \\
3 \cdot 5 \\
3 \cdot 5 \\
3 \cdot 5 \\
18 \\
3 \cdot 5 \\
3 \cdot 5 \\
1 \cdot 8 \\
1.8 \\
180 \\
35 \\
71 \\
35 \\
35 \\
35 \\
35 \\
35\end{array}$ & $\begin{array}{l}U \\
U \\
U \\
U \\
U \\
U \\
U \\
U \\
U \\
U \\
U \\
U \\
U \\
U \\
U \\
U \\
U \\
U \\
U \\
U \\
U \\
U \\
U \\
U \\
U \\
U \\
U \\
U\end{array}$ \\
\hline
\end{tabular}

FORM I PEST

$3 / 90$

B. 27 
ID

PESTICIDE ORGANICS ANALYSIS DATA SHEET

EPA SAMPLE NO.

Lab Name: ENSECO-CAL

Contract: 68-D0-0162

BSSD127

Lab Code: ECAL Case No.: 65147 SAS No.:

SDG NO.: BS -124

Matrix: (soil/water) soIL

Sample wt/vol: $\quad 30.0(\mathrm{~g} / \mathrm{mL}) \mathrm{G}$

* Moisture: 12 decanted: (Y/N) N

SONC

Extraction: (SepF/Cont/Sonc) SONC

5000 (uL)

Lab Sample ID: 65147-23

Concentrated Extract Volume:

Lab File ID: NA

Injection volume: 1.00 (UL)

GPC Cleanup: $\quad(Y / N) Y \quad$ pH: 7.4

Date Received: 07/30/92

Date Extracted: 07/30/92

Date Analyzed: 08/26/92

Dilution Factor: $\quad 1.00$

Sulfur cleanup: $(Y / N) Y$

CONCENTRATION UNITS:

CAS NO. COMPOUND (ug/L or ug/Kg) UG/KG $\quad Q$

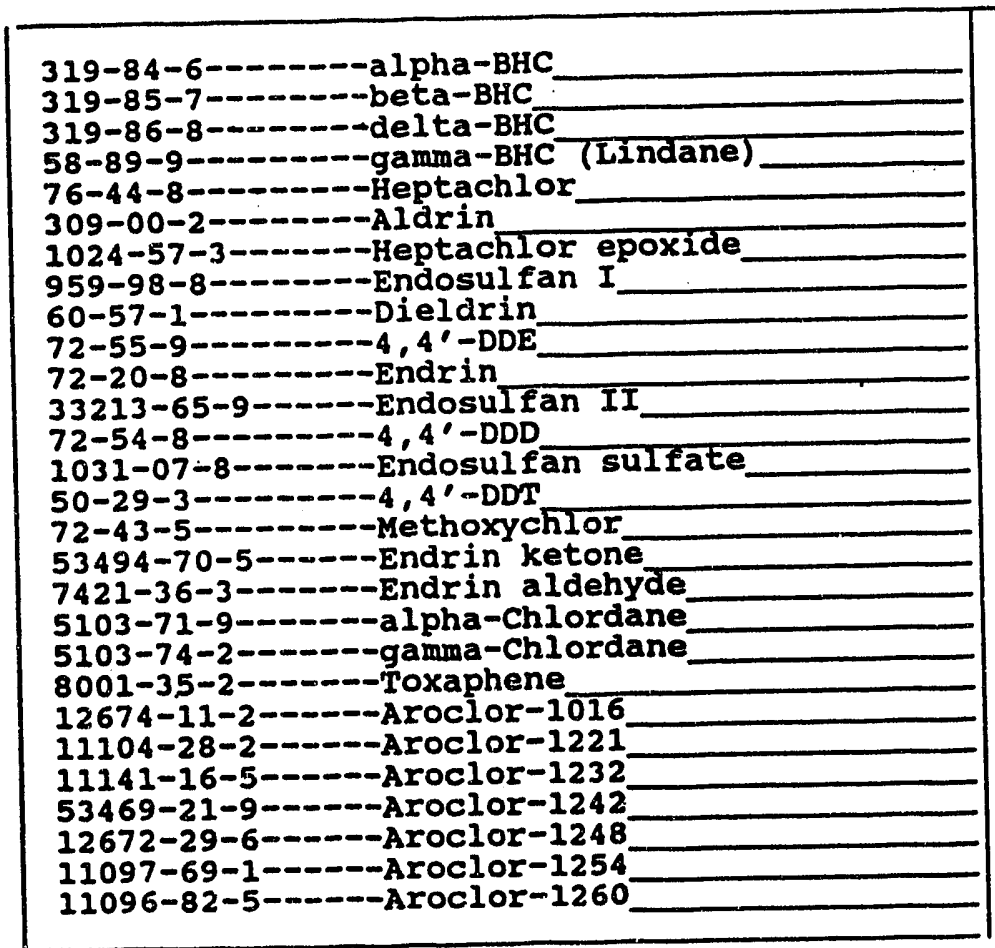

\begin{tabular}{r|l|}
1.9 & $U$ \\
1.9 & $U$ \\
1.9 & $U$ \\
1.9 & $U$ \\
1.9 & $U$ \\
1.9 & $U$ \\
1.9 & $U$ \\
1.9 & $U$ \\
3.7 & $U$ \\
3.7 & $U$ \\
3.7 & $U$ \\
3.7 & $U$ \\
3.7 & $U$ \\
3.7 & $U$ \\
3.7 & $U$ \\
19 & $U$ \\
3.7 & $U$ \\
3.7 & $U$ \\
1.9 & $U$ \\
1.9 & $U$ \\
190 & $U$ \\
37 & $U$ \\
76 & $U$ \\
37 & $U$ \\
37 & $U$ \\
37 & $U$ \\
37 & $U$ \\
37 & $U$ \\
\hline
\end{tabular}




\section{DISTRIBUTION}

No. of

Copies

2 DOE Office of Scientific and Technical information

AIR FORCE

3 Michael I. Rhoads 11th CEOS/DEVR 21885 2nd Street

Elmendorf AFB, AK 99506-4420

3 Lt. Bobbi Moore 673rd CES/DEV Shemya AFB, AK APO Seattle 98736

Alaska Department of Environmental Conservation

2 Jennifer Roberts Southcentral Regional Office 3601 C Street, Suite 1334 Anchorage, AK 99503

Environmental Protection Agency

2 Mark Ader

Region 10

1200 6th Avenue

Seattle, WA 98101

US Fish and Wildilife Service

2 Walter Stieglitz

Region 7

1011 E. Tudor Road

Anchorage, AK 99503
No. of

Copies

Environmental Management

Operations

2 MA Chamness

1 TL Page

Pacific Northwest Laboratory

1 Publishing Coordination

2 Technical Report Files

CH2M HILL

3 Steve Sedlacek

Jacobs Engineering

1 Chris Williams 600 Seventeenth St., Suite $1100 \mathrm{~N}$ Denver, CO 80202 

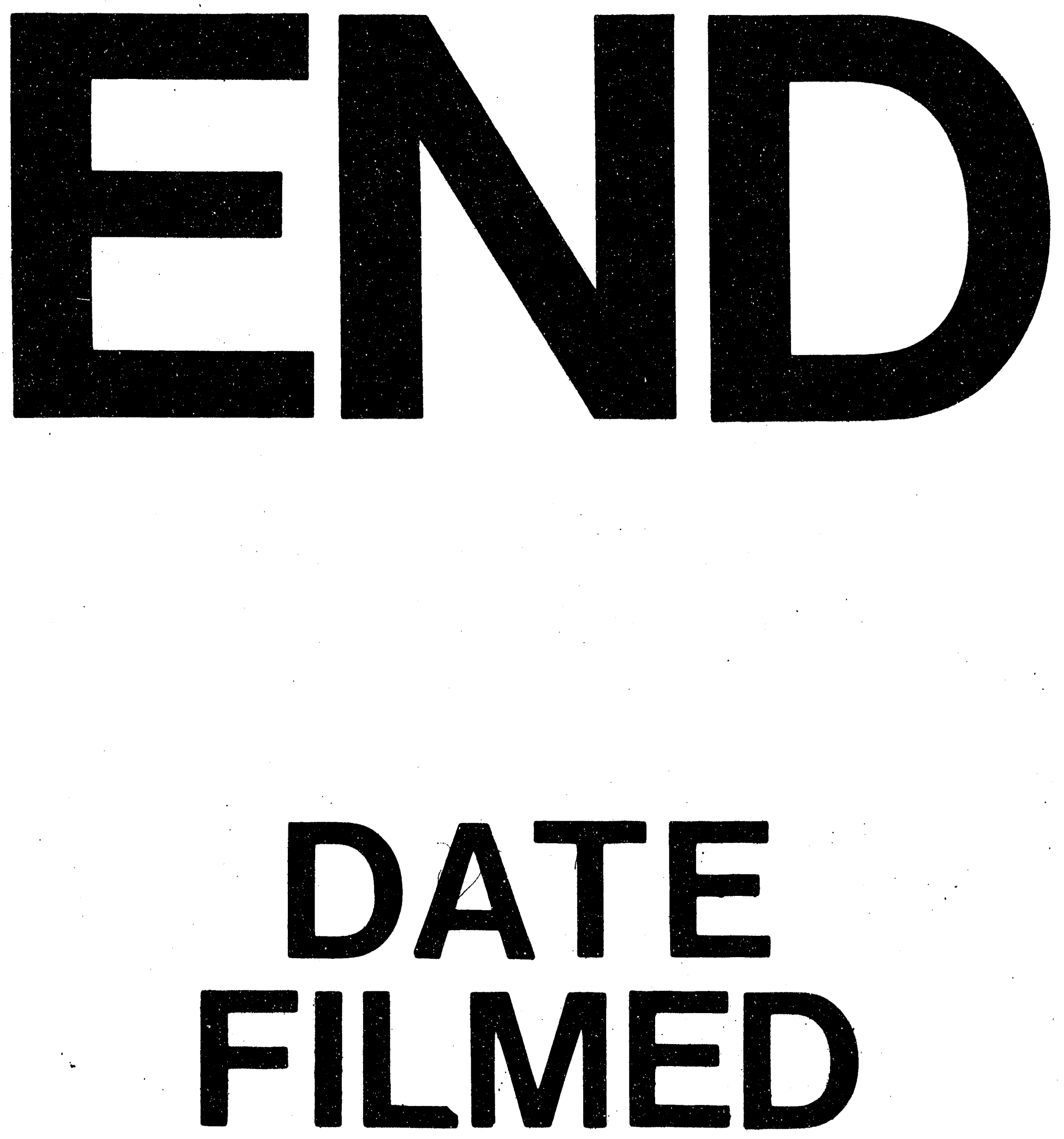

$\mathbf{A}$

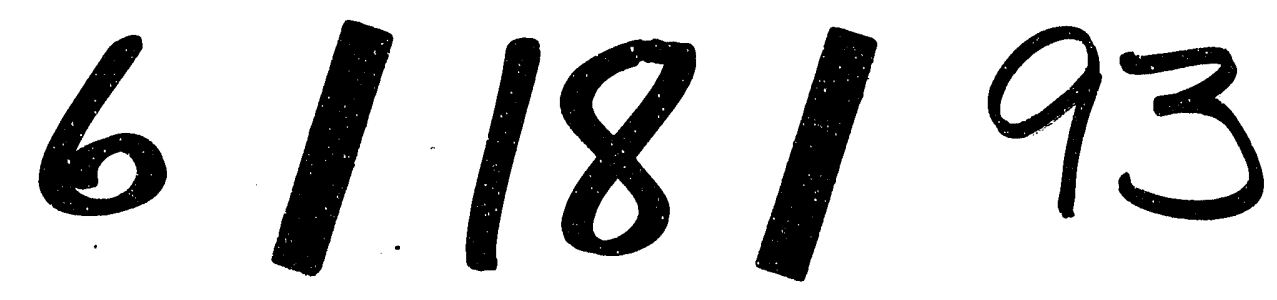


